\title{
ULIHA GÁBOR
}

\section{Az olajár gyengülő makrogazdasági hatásai}

\author{
Két versengő elmélet szintézise
}

\begin{abstract}
Az 1970-es évek olajválságait követő stagflációs periódusok óta gyakorlatilag minden nagyobb áremelkedés alkalmával felerösödnek a kedvezőtlen makrogazdasági hatásokkal kapcsolatos félelmek, miközben a tapasztalat azt mutatja, hogy az importöröket egyre kevésbé érinti az olaj reálárának alakulása. A gyengülö hatások okaként Blanchard-Galí [2007] a gazdaságok hatékonyabb és rugalmasabb müködését jelölte meg, míg Kilian [2010] szerint a 2000 utáni áremelkedést a kedvező világgazdasági környezet fütötte, ami ellensúlyozta a magasabb ár okozta negatív folyamatokat. A tanulmány Kilian [2009] modelljének kiterjesztésével, idöben változó paraméterü ökonometriai eljárással vizsgálja a két megközelítés összeegyeztethetőségét. Az eredmények a hipotézisek egymást kiegészítő kapcsolatára engednek következtetni, azaz a makrogazdasági következmények szempontjából nem maga az ár, hanem annak kiváltó okai lényegesek, ugyanakkor e mögöttes tényezők hatása az elmúlt évtizedekben folyamatosan változott.

Journal of Economic Literature (JEL) kód: C22, C32, E32, Q43.*
\end{abstract}

Az 1970-es évek két nagy olajválsága után tapasztalt stagflációs periódusok standard közgazdasági magyarázata szerint a kőolaj reálárának exogén emelkedése a termelési költségek növelésén keresztül balra tolta az importőr gazdaságok aggregált kínálati görbéjét, ezzel kisebb GDP-t és magasabb munkanélküliséget, illetve árszintet okozva (lásd Mankiw [1999] 274-275. o.). Az 1980-as évek során a kőolaj világpiaci ára helyreállt, mégsem következett be globális fellendülés. Ugyanígy elmaradt a világgazdaság élénkülése az ázsiai válság által kiváltott árzuhanás után, mi több, a 2003-tól megindult tartós drágulás sem okozott recessziót és/vagy gyorsuló pénzromlást az importőr országokban. Az olajárak makrogazdasági hatásainak megfigyelt gyengülését számos tényezővel próbálták magyarázni. Az 1980-as évek eseményeit még igazolni látszott az aszimmetrikus

\footnotetext{
* A szerző köszönetet mond Elek Péternek, Szabó-Bakos Eszternek, Vincze Jánosnak, Várpalotai Viktornak, Varga Balázsnak és a cikk lektorának a tanulmányhoz kapcsolódó értékes megjegyzéseikért.
}

Uliha Gábor, a Budapesti Corvinus Egyetem doktorjelöltje.

A kézirat első változata 2015. szeptember 21-én érkezett szerkesztőségünkbe.

DOI: http://dx.doi.org/10.18414/KSZ.2016.7-8.787 
hatás hipotézise, amely szerint egy áremelkedés hatása abszolút értékben meghaladja egy ugyanolyan mértékủ csökkenés hatását (Mork [1994], Hamilton [2003], Jiménez-Rodríguez-Sánchez [2005], Edelstein-Kilian [2009]). Ez azonban nem ad magyarázatot a 2000 utáni időszakra, amikor az áremelkedés hatása a föbb makrogazdasági mutatókban nem - vagy legalábbis sokáig nem - jelentkezett. A jelenséget megfejteni próbáló tanulmányok egy része a gazdaságok jobb ellenálló képességében (Blanchard-Galí [2007]), mások az olajárváltozás szerkezetében (Kilian [2009], [2010], Bodenstein és szerzőtársai [2012]) keresték a megoldást. Blanchard-Galí [2007] szerint a 2000-es évekre a technológiai fejlődés (egységnyi GDP előállítása kevesebb kőolaj felhasználását igényelte), a rugalmasabb munkaeröpiac, valamint a hatékonyabb monetáris politika tette lehetővé az Egyesült Államokban - és néhány más fejlett gazdaságban - a kedvezötlen makrofolyamatok mérséklődését.

Ezzel szemben a Kilian [2010]-féle nézet szerint az olajárak exogenitásának feltevése hibás identifikációs stratégiát okoz, mivel az árak endogén komponense (nemcsak az árak hatnak a makroaggregátumokra, de azok is az árakra) miatt az elemzésekben alkalmazott ceteris paribus megkötés a valóságban nem lehetséges. A magas olajárak és a velük párhuzamosan megfigyelt magas infláció például nem feltétlenül áll ok-okozati kapcsolatban egymással, elképzelhető, hogy az aggregált kereslet monetáris politika által generált fellendülése okozza mind az árszínvonal, mind az olajár megugrását (Barsky-Kilian [2001]). Kilian [2009] eredményei szerint „nem minden olajársokk egyforma”, így az olajpiaci események eltérő szerkezetében kell keresni a változás eredetét. A két olajválság során nem ugyanazok a tényezők okozták az árak emelkedését, mint a 2000-es években, amikor a bővülő ázsiai kereslet hajtotta felfelé a jegyzéseket, így az Egyesült Âllamokban megfigyelt jobb ellenálló képesség okát valójában az árváltozás szerkezetében (aggregált keresleti sokkok) kell keresni. Az olajárak endogenitásának elmélete az elmúlt években széles körben elfogadottá vált, és kétségkívül konzisztens magyarázatot nyújt a stagflációk elmaradására. Ugyanakkor a két megközelítés - eltérő forrás, megváltozott gazdasági szerkezet - nem zárja ki egymást, elképzelhető, hogy együtt magyarázzák a megfigyelt jelenséget. Ebben a tanulmányban időben változó paraméterü ökönometriai modellek segítségével vizsgáljuk a hipotézisek kompatibilitását az Egyesült Államok példáján, és megmutatjuk, hogy nem csupán az árváltozás forrása számít, de bizonyos esetekben a különböző típusú sokkok negatív hatásai is enyhültek az évtizedek folyamán. Annak megválaszolása, hogy az enyhülő hatást a Blanchard-Galí [2007] által megjelölt tényezők okozták-e, nem célunk eldönteni, itt csupán a folyamat jelenlétét próbáljuk igazolni.

A tanulmány felépítése a következö. Elöször röviden összefoglaljuk az olajár makrogazdasági hatásait elemző irodalom főbb megállapításait, majd bemutatjuk a felhasznált adatokat és módszereket. Kilian [2009] modelljének számításait egy kibővített mintán és változóhalmazon végezzük el, majd az olajpiaci sokkok makrogazdasági hatásainak időbeli változását elemezzük. A robusztussági vizsgálatok eredményeinek ismertetését követően levonjuk következtetéseinket, és felvázoljuk a lehetséges továbblépési irányokat. 


\section{Szakirodalmi áttekintés}

Az olajárak makrogazdasági hatásait két részre, közvetlen és közvetett csatornákra bonthatjuk (Kilian [2014]). Az olajár emelkedése negatívan hat a GDP-re a háztartások csökkenő elkölthető jövedelmén (Dhawan-Jeske [2008], Bodenstein-Guerrieri [2011]), valamint a vállalatok megnövekedett költségein (Rotemberg-Woodford [1996], Atkeson-Kehoe [1999], Finn [2000]) keresztül. Ezzel párhuzamosan az emelkedő termelési költségek inflációt okoznak, ugyanakkor a háztartási oldalon dezinflációs hatásokat figyelhetünk meg. Az - energiafogyasztáson felüli - elkölthető jövedelem redukálása után az egyéb javak iránti kereslet csökken, és ez a hatás annál erösebb, minél rugalmatlanabb az energia iránti kereslet. Márpedig Kilian-Park [2009] azt találta, hogy az exogén olajárváltozásokra az energetikai szektorba sorolható amerikai részvények kevésbé érzékenyek, mint azok, amelyek a végső fogyasztástól függnek (kiskereskedelem, turizmus), ami az energiakereslet alacsony árrugalmasságára utal. Az olajárak emelkedésének közvetlen hatásaként tehát csökken ugyan a GDP, az árszínvonal esetén azonban egymással ellentétes hatások nehezítik a tisztánlátást. A közvetett hatások ráadásul tovább bonyolítják a képet.

Ezek a közvetett hatások azért kerültek a közgazdasági elemzések középpontjába, mert a közvetlen csatornák modellbe illesztésével két komoly probléma is akadt. Egyrészt az olajár emelkedése a modellekben nem okozott a vártnak megfelelő nagyságú recessziót és inflációt, másrészt nem tudta megmagyarázni, miért nem követte a masszív árcsökkenéseket egy erőteljes gazdasági fellendülés. A közvetett hatások beépítése némi segítséget nyújtott ezen hiányosságok kiküszöböléséhez. Kilian [2014] összefoglaló tanulmánya három típust nevez meg: allokációs és bizonytalansági hatást, illetve a monetáris politikai választ. ${ }^{1}$

Az allokációs elmélet lényege, hogy a drágulás visszaveti az olajintenzív termékek keresletét, így a gazdaság termelési szerkezetét a relatíve kevés energiával előallítható áruk és szolgáltatások javára módosítja. Ez a strukturális változás számos igazodási költséggel és piaci súrlódással jár, ami végső soron csökkenti a kibocsátást (Hamilton [1988]). Ezenfelül az emberi és a fizikai tőkének bizonyos formáit egyszerüen nem lehet más iparágakban újrahasznosítani, ami elsüllyedt költségekhez vezet (IMF [2011]). A legrosszabb forgatókönyv szerint pedig egy nagyobb csődhullám a banki mérlegeken keresztül a gazdaság más ágazatait is bajba sodorhatja. Könnyen belátható, hogy ez a fajta átcsoportosítási mechanizmus akkor is müködik, amikor az olaj ára csökken, azaz egy nagyobb elmozdulás az energia árában így is, úgy is strukturális átalakulásokhoz vezet, extraköltséggel terhelve a gazdaságot. Ez azt jelenti, hogy az aktivitást érintő közvetlen hatásokat - az olajár változásának előjelétől függetlenül - az allokációs hatás negatív irányba korrigálja. Tehát a leírt folyamat az olajárak növekedése által okozott GDP-csökkenést felerösíti, míg az árak mérséklődésének pozitív közvetlen hatásait gyengíti.

Ehhez hasonló kimenetre vezet a bizonytalansági hatás. Bernanke [1983] szerint az olajárak volatilitásának növekedése a reálopciós elmélet értelmében a vállalatokat

\footnotetext{
${ }^{1}$ Meg kell jegyeznünk, hogy mindhárom elmélet a reálolajár-változások aszimmetrikus makrogazdasági hatásaira épít, aminek jelenlétére utalnak Mork [1994], illetve Hamilton [2003] eredményei is.
} 
beruházásaik elhalasztására ösztönzi (feltéve, hogy a kifizetés valamilyen módon függ az olaj árától). Ehhez hasonlóan a háztartások a tartós fogyasztási cikkek beszerzését halasztják el (IMF [2011]). Így összességében az allokációs hatáshoz hasonló folyamatot figyelhetünk meg, a bizonytalanság növekedése erösíti a GDP visszaesését és tompítja annak bővülését.

Bernanke és szerzőtársai [1997] amellett érvelnek, hogy az olajválságok során a Fed szigorú monetáris politikája nem enyhítette, inkább mélyítette a válságot. Az olajárak növekedésére ugyanis az irányadó kamatláb emelésével válaszolt, ami tovább fokozta a recessziót, ráadásul a lehorgonyzott inflációs várakozások miatt az árszínvonal csak lassan reagált, így egy ideig a gazdaság visszaesését gyors ütemủ pénzromlás kísérte (stagfláció). Ezzel szemben fordított esetben kevésbé volt „galamblelkü" a Szövetségi Nyíltpiaci Bizottság (Federal Open Market Committee, FOMC), és az olajárak esésénél nem csökkentette olyan mértékben a kamatlábat, mint amenynyire korábban - pozitív irányú elmozdulás mellett - megemelte azt. Így Bernanke és szerzötársai [1997] szerint a Fed monetáris politikája közvetett módon hozzájárult az olajárak makrogazdasági hatásainak megfigyelt alakulásához. A stagflációk monetáris eredete mellett érvel Barsky-Kilian [2001] is.

A közvetett (aszimmetrikus) hatások elemzése ígéretes iránynak tűnt az 1980-as és az 1990-es évek áreséseit követő események, a robusztus gazdasági fellendülés elmaradásának magyarázatára, valamint a stagflációk kialakulásának modellezésére, azonban a 2000-es évek nagy áremelkedéseivel párhuzamos prosperálás már nem fért bele e keretrendszerbe. Az olaj reálárának a növekedése nem érintette az amerikai és más importőr gazdaságok GDP- és inflációs mutatóit, ${ }^{2}$ aminek okát egyesek a gazdaság jobb ellenálló képességében (Blanchard-Galí [2007]), míg mások az olajárak endogenitásában (Kilian [2009], [2010]) vélték felfedezni.

Blanchard-Galí [2007] vektor-autoregresszív (VAR) modellek segítségével arra a következtetésre jutott, hogy az Egyesült Államok, az Egyesült Királyság, Olaszország, Franciaország és részben Németország esetében is csökkent a GDP-deflátor, a fogyasztói árindex (CPI) és a bérinfláció, valamint a GDP és a foglalkoztatás olajárra való érzékenysége. A gazdaságok jobb ellenálló képességét négy tényezővel magyarázták. A technológiai fejlődés eredményeképpen a termelésben jelentősen csökkent a kőolaj felhasználási hányada, azaz egységnyi reál-GDP előállítása kevesebb olajinputot igényelt. A rugalmasabb munkaerőpiacok a sokkokra adott reakcióidőt mérsékelték, és lehetővé tették az optimálishoz közeli kiigazítás elvégzését. A monetáris politikába vetett bizalom növekedése a gazdaságpolitikai beavatkozások hatékonyságát erősítette, a nagy mérséklődés (Great Moderation) utáni évtizedekben az infláció sokkal kevésbé szóródott, a várakozások alacsony és stabil pénzromlási ütem mellett horgonyoztak le. Emellett Blanchard-Galí [2007] megemlíti, hogy korábban más nyersanyagpiacokon is masszív áremelkedések szemtanúi lehettünk, míg a 2000-es években ez elmaradt. Távolabbról nézve azonban ez az állítás nem állja meg a helyét.

\footnotetext{
${ }^{2}$ Bár Hamilton [2009] szerint a 2007 negyedik és 2008 harmadik negyedéve közötti amerikai recesszió magas olajárak hiányában nem alakult volna ki, és az Egyesült Államok lassú, de pozitív GDPnövekedést produkált volna. Ezzel cseng egybe Kilian [2010] megállapítása is, amely szerint a pozitív aggregált keresleti sokkok kifutása erősítette a hozzáadott érték visszaesését.
} 
Ahogy azt később látni fogjuk, a kínai fellendülés fütötte globális növekedés más nyersanyagok keresletét is megemelte ebben a periódusban.

Ezzel szemben Kilian [2010] azzal érvel saját korábbi eredményeire hivatkozva (Kilian [2009]), hogy nem minden olajársokk egyforma, és a termelés volumenét érintő kínálati sokkok impulzusválasz-függvényei szignifikanciájukat és alakjukat tekintve is eltérnek az áremelkedést okozó keresleti sokkok hatásaitól. Utóbbiaknál a világpiaci aktivitást érintő, ezáltal a nyersanyagok összességére ható aggregált, illetve a kifejezetten az olajpiacot érintő specifikus keresleti sokkokat különböztette meg. Érvelése szerint - amit nemsokára egy kibővített mintán és változóhalmazon fogok bemutatni - az eltérő sokkok makrogazdasági hatásai különbözők, és időben folyamatosan változott a reálolajár hullámzását meghatározó tényezők fontossági sorrendje. Ebből következően a 2000-es években azért nem láttunk recessziót, mert a kínai növekedés fütötte nyersanyagár-emelkedések negatív hatását a kedvező globális környezet, azaz a gyors világgazdasági növekedés egy darabig ellensúlyozni tudta.

Az olajár változásának strukturális elemzése mára elfogadott eszközzé vált a szakirodalomban. Kilian-Park [2009] az amerikai részvényárak és az olajpiaci sokkok összefüggéseit vizsgálta, Li-Zhao [2011] Kilian modelljét az Egyesült Államok pénzkínálatával bővítette, míg Peersman-Van Robays [2011] 11 országra építette SVAR modelleket és becsülte meg a sokkok makrogazdasági hatásait. Anzuini és szerzötársai [2014] az Egyesült Államok aktivitási és inflációs idősoraira illesztettek VAR modellt egy kétlépcsős eljárás segítségével, és közelítették a biztonsági vásárlások által kiváltott olajár-emelkedés következményeit. Peersman-Stevens [2010], illetve Bodenstein és szerzőtársai [2012] DSGE-keretben elemezték az árváltozás szerkezeti összetevőinek hatásait. Baumeister-Peersman [2012], [2013] pedig időben változó paraméterü modelleket használtak az olajpiaci volatilitásnak és a kínálati sokkok makrogazdasági hatásainak leírására. Utóbbihoz kapcsolódik jelen tanulmány is, hiszen célja, hogy Kilian [2009] modelljéből kiindulva megmutassa a különbözö típusú olajpiaci (kínálati, aggregált és specifikus keresleti) sokkok makrogazdasági hatásainak időbeli változását, ezáltal rávilágítson a Blanchard-Galí [2007] elméletével való kompatibilitásra.

\section{Adatok}

Az elemzés során nyersanyagpiaci és makrogazdasági változókkal dolgozunk. A nyersanyagpiaci változók (az olaj világpiaci kínálatának, a világpiaci reálaktivitásnak és az olaj reálárának idősorai) 1973 januárjától 2014 decemberéig terjednek. A kínálati adatok az Energy Information Administration (EIA) adatbázisából származnak, ${ }^{3}$ mértékegységük ezer hordó/nap. Ugyanitt lehet hozzáférni az Egyesült Államok által importált olaj finomítói felvásárlási áraihoz (dollár/hordó), s ezt az amerikai fogyasztói árindexszel diszkontálva megkaptuk az elemzés során használt

\footnotetext{
${ }^{3}$ http://www.eia.gov/petroleum/data.cfm.
} 
reálváltozót (1974. januári dollár/hordó). ${ }^{4}$ Mivel a finomítói árak idősorai csak 1974 januárjától állnak rendelkezésre, ezért a megelőző egy év adatait Barsky-Kilian [2001] alapján számoltuk vissza. Az 1. ábrán az import olaj reálárát és a kínálati idősort találjuk. Látható, hogy az 1980 -as évek elején mért csúcsról az OPEC árbefolyásoló erejének csökkenése miatt a jegyzés nagyot esett, és a 2000 -es évek elejéig nem is tudott tartósan elmozdulni ebből a helyzetből. Ezt követően egészen a gazdasági válságig emelkedett, onnan megint visszacsúszott, majd 2014 közepéig egy - a korábbi évtizedekhez mérten - magasabb szinten stabilizálódott. A globális nyersolajtermelés az 1970-es évek végén jelentősen csökkent, és az addigi napi 60 millió hordó helyett mintegy fél évtizeden át az 50-55 millió hordós sávban mozgott. A szaúdiak stratégiaváltása után azonban hirtelen növekedett (ez okozta az árak nagymértékü csökkenését), majd folyamatosan emelkedve 2014 végére 80 millió hordó/nap közelébe került, ${ }^{5}$ amit az OPEC-en kívüli termelés felfutása, illetve az ennek következtében megváltozott OPEC-stratégia (a piaci részesedés megtartására való törekvés) egyaránt elősegített. Érdekes megfigyelés, hogy kisebb-nagyobb megszakításokkal ugyan, de a termelés folyamatosan nőtt, nem jellemezte az árakéhoz hasonló magas volatilitás.

\section{1. ábra}

A globális nyersolajtermelés és az olaj amerikai reálárának idősorai (1973. január-2014. december)

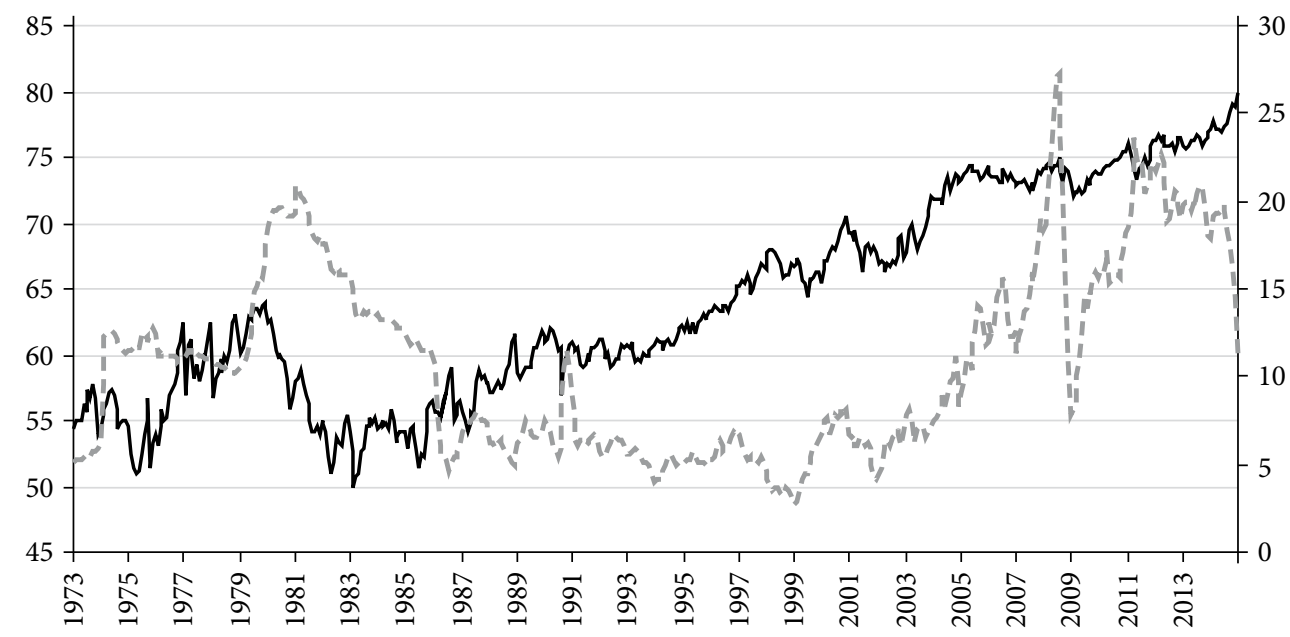

— Globális nyersolajtermelés (millió hordó/nap, bal tengely)

- - - Import olaj finomítói felvásárlási ára (1974. januári dollár/hordó, jobb tengely)

Forrás: Energy Information Administration (EIA).

${ }^{4}$ Blanchard-Galí [2007] a WTI olajfajtát használta, amit az amerikai GDP-deflátor segítségével diszkontált. A fogyasztói árindexet és az importtermék finomítói felvásárlási árait Kilian [2009] alkalmazta. A fogyasztói árindex előnye, hogy az implicit árindexszel (GDP-deflátor) szemben havi bontásban is hozzáférhető.

${ }^{5}$ Gyakran találkozni napi 90 millió hordó fölötti kínálati adatokkal. Az eltérést definícióbeli különbségek magyarázzák. 
A világgazdasági reálaktivitás idősorait Lutz Kilian szerkesztette, az adatok az ő honlapjáról származnak, és elöször Kilian [2009] tanulmányban szerepelnek. Mivel látens változóról van szó, maga a mutató csak egy közelítő változó, ami vízi szállítási adatokból származik, és célja, hogy számszerüsítse a nyersanyagok iránti világpiaci kereslet változását. A hogy később látni fogjuk, erre azért van szükség, hogy a modellezés során külön lehessen választani aggregált és specifikus (kizárólag az olajpiacon megjelenő) részre az olajkereslet változásait. A globális GDP ugyanis erre nem igazán alkalmas. Egyrészt az árfolyamok kezelése, valamint az eltérő módszerrel számolt GDP-k aggregálása nem triviális feladat, másrészt nem elhanyagolható körülmény, hogy miből származik a globális hozzáadott érték változása, mivel az ipar és a szolgáltatások energiaigénye jelentősen eltér egymástól. A mutató részletes leírása megtalálható Kilian [2009] 1056. oldalán, itt csak annyit érdemes megjegyezni, hogy a száraz rakomány (dry cargo) szállítási díjának (freight rate) időbeli alakulásából származik, és logaritmizálás, valamint lineáris trendszürés után alkalmas a ciklikus változások megragadására. ${ }^{6}$

Az idősor ábrázolásából kiderül, hogy a két olajválság idején nagy volt a reálaktivitás (2. ábra), azaz nemcsak az olaj, de a többi nyersanyag iránt is megnőtt a kereslet (összhangban Barsky-Kilian [2001] megállapításával), és ugyanez látszik 2002-től kezdve. A gazdasági és pénzügyi válság hatására azonban visszaesett a mutató, és a vizsgálati periódus végén ismét a negatív tartományba került, azaz a nyersanyagok iránti kereslet elmaradt a hosszú távú trendtől, ahogy arra egyébként a szén, a földgáz és számos más nyersanyag áresése is utal.

\section{2. ábra}

Globális reálaktivitás index (1973. január-2014. december)

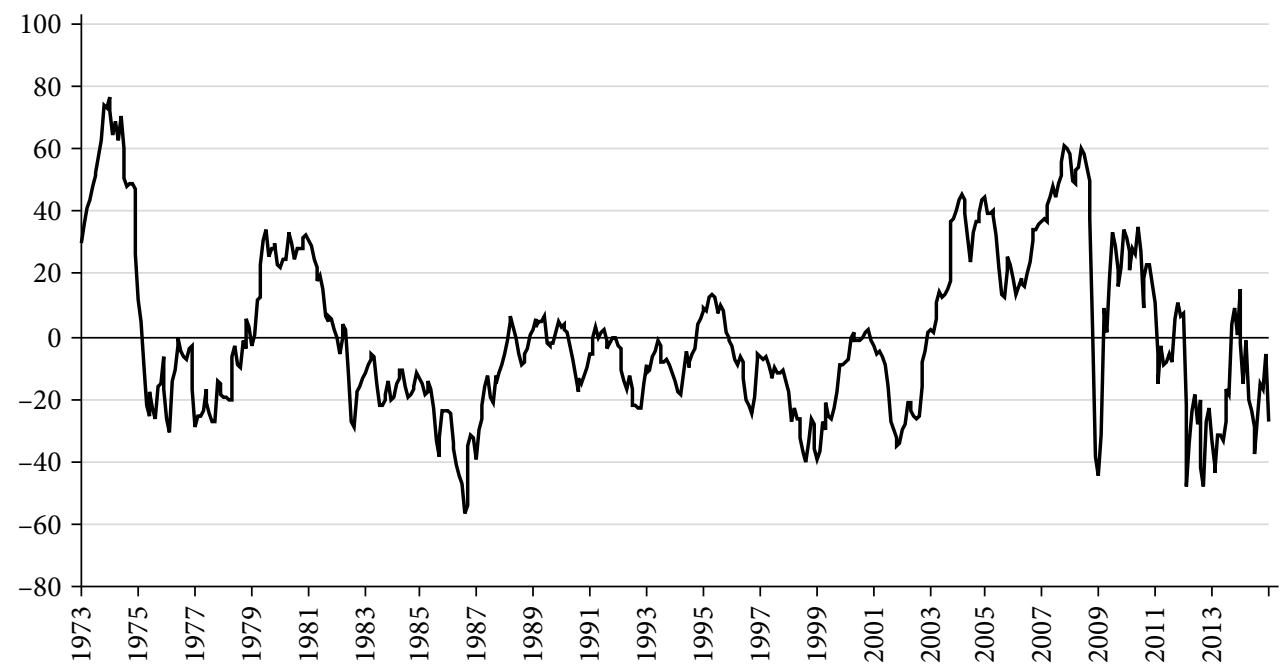

Forrás: http://www-personal.umich.edu/ lkilian/reaupdate.txt.

\footnotetext{
${ }^{6}$ A trendszűrés a technológiai fejlődés árcsökkentő hatása miatt szükséges. Az eredeti idősor emiatt nem stacionárius. Meg kell jegyeznünk azonban, hogy a lineáris megközelítés közel egyenletes (és törésmentes) technológiai fejlődést feltételez, aminek teljesülése nem garantált.
} 
A számítások a kitermelés logaritmikus differenciájával, valamint a reálolajár logaritmusával történtek, a kitermelés esetében a havi növekedési ütemet évesítettük, mégpedig a kapott $d$ log érték 12-vel történő felszorzása révén. A könnyebb értelmezhetőség kedvéért a modellben mindhárom mutatót 100-zal szoroztuk, összhangban Kilian [2009] megközelítésével, ami az eredmények összehasonlíthatóságát segíti.

Az olajárak makrogazdasági hatásait négy szezonálisan szűrt változón vizsgáltuk. Ezek sorrendben a 2009-es áron számolt reál-GDP, a munkanélküliségi ráta, a fogyasztói árindex (CPI) és a GDP-deflátor. Mindegyik változó az Egyesült Államokra vonatkozik, és a Federal Reserve adatbázisából származik. ${ }^{7}$ A GDP és a GDPdeflátor adatai csak negyedéves, a másik két változóé havi gyakoriságúak, de az elemzésben az utóbbiak is negyedéves aggregátumként szerepeltek, mégpedig úgy, hogy a kapott változó a negyedév során bekövetkező változást mutassa:

$$
C P I^{Q}=\ln \left(C P I_{M 3}^{Q}\right)-\ln \left(C P I_{M 3}^{Q-1}\right),
$$

ahol $C P I^{\mathrm{Q}}$ a $C P I$ negyedéves aggregátumát, $C P I_{M 3}^{Q}$ az adott negyedév, $C P I_{M 3}^{Q-1}$ pedig az előző negyedév utolsó hónapjára jellemző $C P I$ értékét jelöli. A munkanélküliségi ráta $(U)$ esetén is hasonló az eljárás, de logaritmizálás nélkül:

$U^{Q}=U_{M 3}^{Q}-U_{M 3}^{Q-1}$.

A negyedéves növekedési ütemeket minden változó esetén felszorzással évesítettük. A 3. ábráról látható, hogy a munkanélküliségi ráta kontraciklikus változó, konjunktúra idején csökken, míg dekonjunktúra idején emelkedik. Ennek megfelelöen nagyobb pozitív kilengések (a ráta hirtelen emelkedése) a két olajválság mellett az 1980 -as és 1990-es évek fordulóján, a 2000-es évek elején (dotcom válság) és 2009ben figyelhetők meg. Az utolsó néhány évben az amerikai gazdaság fellendülését a GDP növekedése és a munkanélküliségi ráta csökkenése kísérte.

Az inflációs mutatók tekintetében megállapítható, hogy míg az 1980-as évek elejéig magasan tartózkodtak, utána kivétel nélkül stabilizálódtak (Great Moderation), és csak 2008 harmadik negyedévében, illetve az azt követő rövid időszakban láthatunk nagy volatilitást (4. ábra). Ekkor a kibontakozó gazdasági és pénzügyi válság hatására negatív infláció alakult ki, a fogyasztási javak árváltozását mérő CPI egy rövid időre (2008. IV. negyedév) 10-15 százalékos mínuszt is produkált, ami 2,5-4 százalékos árcsökkenésnek felel meg egyetlen negyedév alatt. Ehhez hasonló utat járt be a GDP-deflátor is, de jóval kisebb volatilitás mellett. A 2014 utolsó negyedévében tapasztalt visszaesésre gyakori magyarázat az olajárak csökkenése, ám mint arról már szó esett, nemcsak az olaj, hanem más nyersanyagok jegyzése is sokat csökkent ebben az időszakban, ráadásul a Federal Reserve is felhagyott a korábbi mennyiségi lazítási programmal, így nem feltétlenül helyes egyetlen tényezőnek tulajdonítani a teljes korrekciót. Erre a tanulmány későbbi részében még visszatérünk.

Az elemzés során használt vektor-autoregresszív (VAR) modell megköveteli a változók stacionaritását, ezért a leíró statisztikák mellett az 1. táblázat tartalmazza az

\footnotetext{
${ }^{7}$ https://research.stlouisfed.org/fred2/categories.
} 


\section{3. ábra}

A GDP és a munkanélküliségi ráta évesített negyedéves növekedési ütemei (1973. I. negyedév-2014. IV. negyedév)

Százalék

Százalék

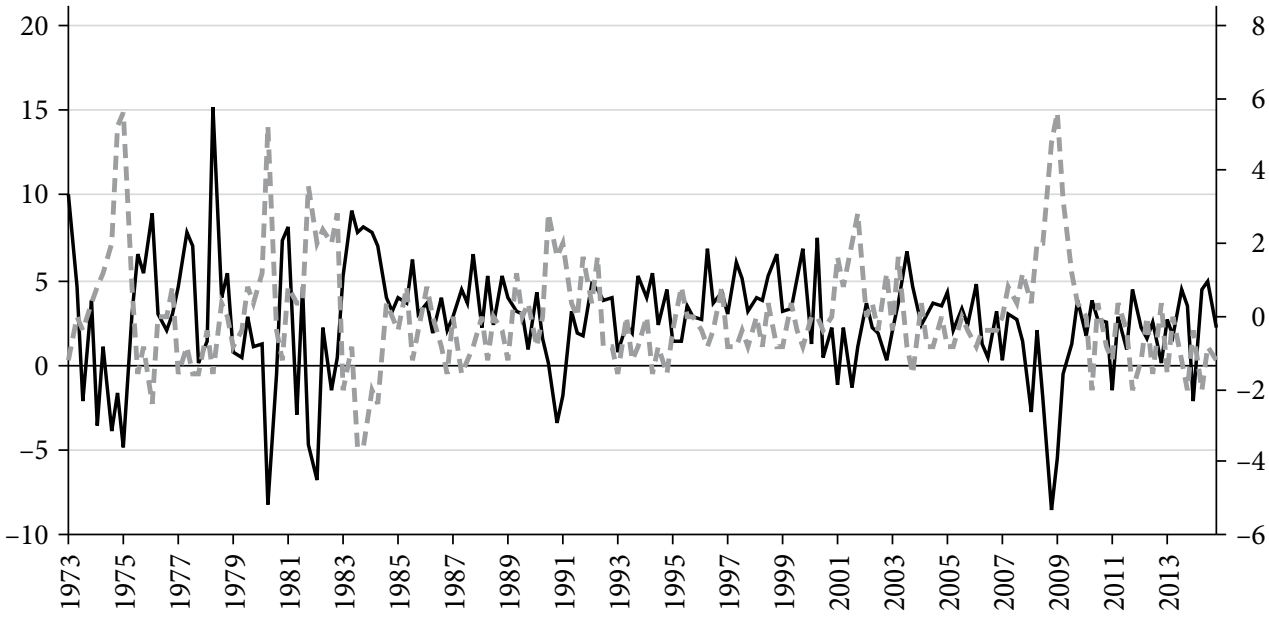

— A GDP növekedési üteme (bal tengely)

- - - A munkanélküliségi ráta változása (jobb tengely)

Forrás: Federal Reserve Economic Database (FRED).

4. ábra

A fogyasztói árindex és a GDP-deflátor évesített negyedéves növekedési ütemei (1973. I. negyedév-2014. IV. negyedév)

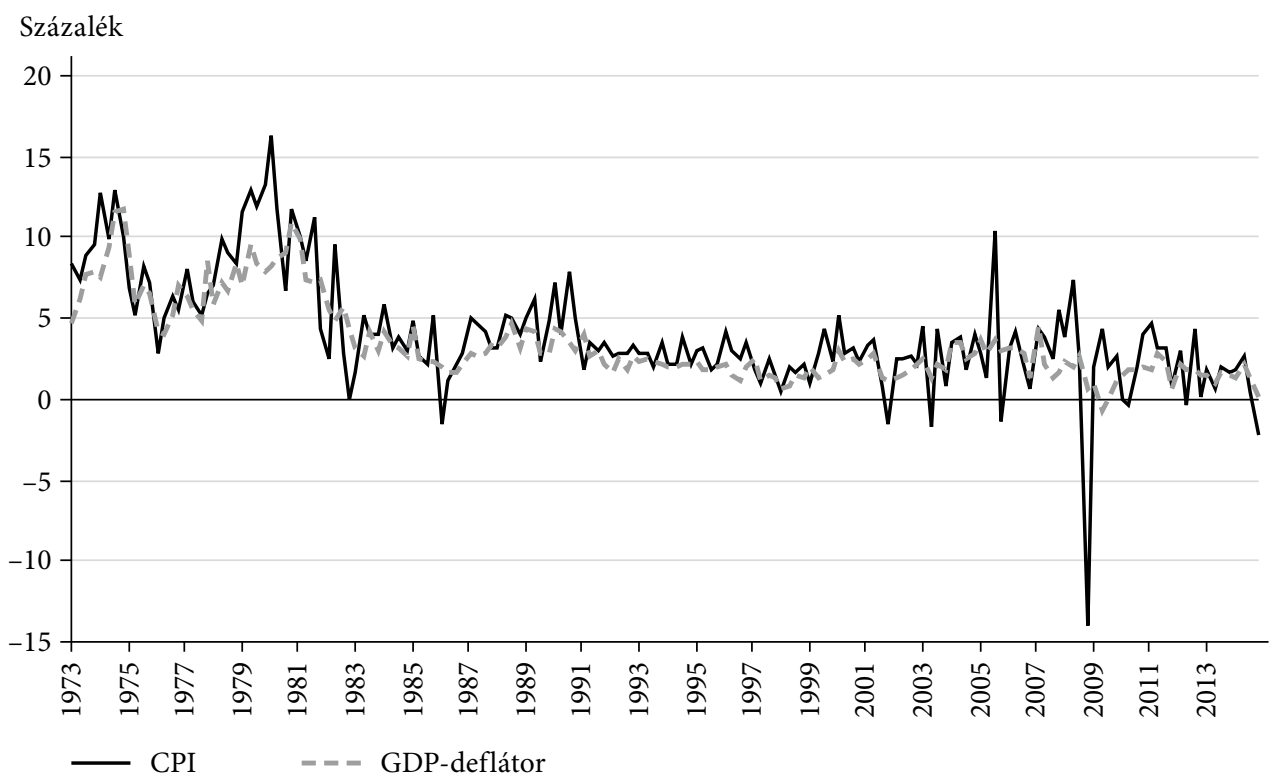

Forrás: Federal Reserve Economic Database (FRED). 
összes (tehát nemcsak a VAR modellben, de a későbbi vizsgálatokban is használt) idősorra vonatkozó kiterjesztett Dickey-Fuller- (ADF) próbák eredményeit (MacKinnon [1996]). A nullhipotézis minden esetben az, hogy a folyamat eltolásos véletlen bolyongást követ, míg az alternatív hipotézis szerint egy nem nulla várható értékü, stacionárius idősorról van szó. Mind az olajpiaci (termelés, aktivitás, olajár), mind a makrogazdasági változók a korábban bemutatott, transzformált alakban szerepelnek (logaritmikus differencia, évesítés stb.), de míg az első csoportnál havi, addig a másodiknál negyedéves bontásban. A mintaidőszak 1973-tól 2014-ig terjed. Az eredményekből kitünik, hogy 10 százalék feletti p-érték csupán a GDP-deflátor esetében fordul elö. Ugyanakkor ez a változó nem szerepel a VAR modellben, így a stacionaritás hiánya sem okoz problémát, ezért újabb transzformációra már nincs szükség.

\section{1. táblázat}

A változók leíró statisztikái és az egységgyökpróbák (ADF) p-értékei

\begin{tabular}{|c|c|c|c|c|c|c|c|}
\hline & \multirow{2}{*}{$\begin{array}{l}\text { Termelés } \\
\text { (százalék) }\end{array}$} & \multirow{2}{*}{$\begin{array}{c}\text { Aktivitási } \\
\text { index }\end{array}$} & \multirow{2}{*}{$\begin{array}{l}\text { Olajár- } \\
\text { mutató }\end{array}$} & CPI & GDP & $\begin{array}{l}\text { GDP- } \\
\text { deflátor }\end{array}$ & \multirow{2}{*}{$\begin{array}{c}\begin{array}{c}\text { Munka- } \\
\text { nélküliség }\end{array} \\
\text { (százalékpont) }\end{array}$} \\
\hline & & & & \multicolumn{3}{|c|}{ (százalék) } & \\
\hline Átlag & 0,9 & 0,26 & 12,67 & 4,1 & 2,7 & 3,5 & 0,0 \\
\hline Medián & 2,3 & $-5,27$ & 22,55 & 3,2 & 3,0 & 2,6 & 0,0 \\
\hline Maximum & 78,0 & 76,56 & 117,59 & 16,3 & 15,3 & 11,8 & 5,6 \\
\hline Minimum & $-118,9$ & $-56,71$ & $-114,78$ & $-13,9$ & $-8,5$ & $-0,7$ & $-3,6$ \\
\hline Szórás & 19,0 & 25,73 & 51,22 & 3,6 & 3,3 & 2,5 & 1,5 \\
\hline ADF (százalék) & 0,0 & 0,80 & 5,50 & 5,0 & 0,0 & 24,0 & 0,0 \\
\hline$N$ & 503 & 503 & 503 & 168 & 168 & 168 & 168 \\
\hline
\end{tabular}

Forrás: Energy Information Administration: termelés évesített növekedési üteme, reálolajár logaritmusának 100-szorosa, Federal Reserve Economic Database: évesített CPI és GDPdeflátor infláció, GDP-növekedés és a munkanélküliségi ráta változása (százalékpont), Kilian: reálaktivitási index.

\section{Módszertan}

A bemutatásra kerülő modellek Kilian [2009] cikkére épülnek, ahol az olajpiaci sokkok identifikálása SVAR (strukturális vektor-autoregresszív) modellel történt, Cholesky-dekompozíció mellett. A VAR struktúrája a következő: ${ }^{8}$

$A_{0} z_{t}=\alpha+\sum_{i=1}^{24} A_{i} z_{t-i}+\varepsilon_{t}$

ahol $z$ az endogén változók, $\alpha$ a konstansok, $\varepsilon$ pedig az ortogonális és autokorrelálatlan hibák oszlopvektora. A $z$ vektor elemei sorrendben a világpiaci olajtermelés változása

\footnotetext{
${ }^{8}$ A modell részletesebb leírása megtalálható Kilian [2009] 1058. oldalán.
} 
(a kitermelési volumenekből logaritmikus differenciával számolva), a világpiaci reálaktivitás és az olaj reálárának logaritmusa. Az adatok havi bontásúak, a minta 1973 januárjától 2014 decemberéig tart. A (3) strukturális modell persze közvetlenül nem becsülhető, csak annak redukált változata:

$z_{t}=\beta+\sum_{i=1}^{24} B_{i} z_{t-i}+e_{t}$

ahol $\beta=A_{0}^{-1} \alpha, B_{i}=A_{0}^{-1} A_{i}$ és $e_{t}=A_{0}^{-1} \varepsilon_{t}$. Az impulzusválasz-függvények generálásához további feltevésekre van szükség. Kilian [2009] az említett Choleskydekompozíciót használta identifikációs stratégiának:

$e_{t}=\left[\begin{array}{c}e_{t}^{\text {kitermelési }} \\ e_{t}^{\text {réalaktivitás }} \\ e_{t}^{\text {realár }}\end{array}\right]=\left[\begin{array}{ccc}a_{11} & 0 & 0 \\ a_{21} & a_{22} & 0 \\ a_{31} & a_{32} & a_{33}\end{array}\right]\left[\begin{array}{c}\varepsilon_{t}^{\text {kitermelési }} \\ \varepsilon_{t}^{\text {réalaktivitás }} \\ \varepsilon_{t}^{\text {realár }}\end{array}\right]$.

Kilian [2009] a kitermelés idősorából származó innovációkat olajkínálati sokkoknak nevezi, a reálaktivitás innovációjának azon részét, amelyet a kínálati sokk nem magyaráz, aggregált keresleti sokknak (ami az olaj és más nyersanyagok iránt egyidejüleg jelentkezö keresletnövekedést takarja). Végül az olajár idősorában lévő innovációk azon részét, amelyet az előző kettőből egyik sem magyaráz, olajspecifikus keresleti sokk néven definiálja, és az elővigyázatossági vásárlásokkal hozza összefüggésbe. A feltevések szerint a reálaktivitás és az olajár változására a termelök nem tudnak ugyanabban a hónapban reagálni, amit a kitermelési volumen módosításának magas költsége (technológiai akadályok), valamint a bizonytalanság (tartósan magas/alacsony marad-e az ár) magyaráz.

A következö feltevés: a világpiaci reálaktivitást is leghamarabb egy hónapos késéssel képes befolyásolni az olaj árának változása. Ezt magyarázhatja a megkötött szerződések miatti rugalmatlanság, illetve konzisztens azzal, amit a reálár- és aktivitás-idősorok dinamikájában tapasztalunk, hiszen a nagyobb árváltozásokat sohasem követte az aktivitás egyidejü elmozdulása. Az ár viszont gyorsan, akár ugyanabban a hónapban képes reagálni a másik két változó mozgására, ami a piac likviditásából és az árak gyors alkalmazkodóképességéből következik. Látható, hogy a havi bontású adatokra azért van szükség, mert negyedéves alapon ez az egyszerü felírás már érvényét vesztené.

A SVAR egyenletenként becsülhetö OLS-sel, a standard hibák pedig GoncalvesKilian [2004] bootstrap módszere alapján számolhatók. ${ }^{9}$ Innen a sokkok idősorai is kinyerhetők, így a különböző makrogazdasági aggregátumokra való hatásuk is vizsgálható. Az olajkínálati sokk a termelés változását, az aggregált keresleti sokk nemcsak az olaj, hanem az egyéb nyersanyagok iránti növekvő keresletet, az olajspecifikus keresleti sokk pedig az elővigyázatossági vásárlásokat jellemző innovációkat foglalja

\footnotetext{
${ }^{9}$ A modell becslése MATLAB-ban történt. A Kilian [2009] által használt eredeti fájlok az American Economic Review honlapján (https://www.aeaweb.org/articles.php?doi=10.1257/aer.99.3.1053) érhetők el. A konfidencia-intervallumok számításához 50 ezer ismétlést használtunk.
} 
magában. ${ }^{10}$ Mivel a GDP és a GDP-deflátor csak negyedéves bontásban hozzáférhető, a makrohatások számszerüsítésénél a sokkok negyedéves átlagával érdemes számolni:

$\hat{\xi}_{j t}=\frac{1}{3} \sum_{i=1}^{3} \hat{\varepsilon}_{j t i}$,

ahol $\hat{\xi}_{j t}$ a $j$-edik típusú (kínálati, aggregált vagy specifikus keresleti) sokk átlagos becsült értéke a $t$-edik negyedévben, $\hat{\varepsilon}_{j t i}$ pedig a j-edik típusú sokk becsült értéke a $t$-edik negyedév $i$-edik hónapjában $(i=1,2,3)$. A makrogazdasági idősorok ezután regresszálhatók az exogén sokkokkal, mivel a hibatag és a regresszorok korrelálatlansága esetén a parciális hatások OLS-becslése torzítatlan és konzisztens. Az egyenletek bal oldalán a már bemutatott makrogazdasági változók szerepelnek $\left(\Delta y_{t}\right)$, míg a jobb oldalon egy konstans tag $(\delta)$, és a vizsgált sokkhatás 13 negyedévi értéke (az egyidejü, illetve a megelőző három év sokkjai együtt):

$\Delta y_{t}=\delta+\sum_{i=0}^{12} \theta_{i} \hat{\xi}_{j t-i}+u_{t}$

ahol $\theta_{i}$ jelöli a sokknak a függő változóra vonatkozó, $i$ negyedévvel későbbi parciális hatását. A fenti típusú egyenletböl összesen 12 becslés készül, a három sokk és a négy makrogazdasági változó összes kombinációját végigpróbálva. Mivel előfordulhat, hogy a hibatagoknál autokorreláció lép fel, ezért a konfidencia-intervallumokat block bootstrap eljárással számoltuk ki. ${ }^{11}$

Hangsúlyoznunk kell, hogy az eljárás a Kilian-féle VAR-ból származó sokkok exogenitására épül, ám elképzelhető, hogy az Egyesült Államok világgazdaságban betöltött szerepe, valamint kiterjedt olajszektora miatt ez nem teljesül, és az egyenletek becslésekor endogenitási probléma lép fel. Például a makrováltozók hatással lehetnek a globális olajpiac müködésére, adott esetben magát a sokkot is kiválthatják. Ennek ellenőrzésére Granger-oksági teszteket végeztünk, amelyekből kiderült, hogy a keresleti sokkok esetén nem áll fenn ilyen probléma. ${ }^{12}$

A kínálati sokkoknál azonban más a helyzet. A GDP bővülési ütemének esetében különösen erös a Granger-oksági kapcsolat jelenléte, és bizonyos beállítások (késleltetésszám) mellett a GDP-deflátor és a fogyasztói árindex (CPI) növekedéséről is ugyanez mondható el. Emiatt a kínálati sokkok makrogazdasági hatásaira kapott eredményeket fenntartással kell kezelni.

Szintén a kínálati sokkokkal függ össze egy másik, inkább értelmezésbeli probléma. Amennyiben az elővigyázatossági vásárlások élénkülése egy olyan lehetséges (például katonai konfliktus miatti) termeléskiesés miatt történik, ami később valóban

${ }^{10}$ Kilian [2009] végig elővigyázatossági vásárlásokat említ, de alighanem ebbe a tagba kerülnek a tágabb értelemben vett spekulációs keresletet érintő sokkhatások is, ha van egyáltalán érdemi szerepük. A témáról lásd bővebben Hamilton [2009], Peersman-Stevens [2010], Fattouh és szerzötársai [2013], Kilian-Murphy [2013], Knittel-Pindyck [2013], Fattouh-Mahadeva [2014], illetve Kilian-Lee [2014].

${ }^{11} 4$-es blokkméret és 50 ezer ismétlés mellett. Az eljárás kezeli az esetleges autokorrelációból adódó torzítást, de nem veszi figyelembe, hogy az egyenlet jobb oldalán generált regresszorok szerepelnek.

${ }^{12}$ A szokásos szignifikanciaszintek mellett nem utasíthatók el az „X makrováltozó nem Grangeroka az Y sokknak" jellegü nullhipotézisek. 
bekövetkezik, akkor az árak emelkedését a termelés vagy a várakozások számlájára írjuk? Az első esetben a kínálati sokk becsült hatásaihoz hozzá kell adni az általa kiváltott készletezési kereslet hatásait. Az eredmények értelmezésekor a második megközelítést alkalmazzuk, mivel nem lehet egyértelmüen eldönteni, hogy a készletezési kereslet felfutásának mekkora része kötődik egy később megvalósuló eseményhez.

Miután Kilian [2009] modelljeit a kibővített adatbázison futtatjuk, megvizsgáljuk az olajpiaci sokkok makrogazdasági hatásainak időbeli változását, ami Kilian eredményeit új megvilágításba helyezi. Szignifikáns eltérések felfedezése esetén elmondható, hogy a két versengő elmélet (Kilian [2010], illetve Blanchard-Galí [2007]) kompatibilis egymással, és mindkét tényező (eltérő jellegü olajpiaci folyamatok, ellenállóbb makrogazdasági struktúra) szerepet játszott az olajár gyengülö hatásában. Az időben változó paraméterü ökonometriai modellek becslése Kalman-szürő segítségével történik, ahol a fenti egyenletek paraméterei a látens változók. ${ }^{13} \mathrm{~A}$ Kalman-szürő lényegében egy állapot-tér-modell, ahol az állapot és megfigyelési egyenletek a következő alakot öltik:

$\nu_{t+1}=F \nu_{t}+\mu_{t+1}$

$z_{t}=G^{T} x_{t}+H^{T} \nu_{t}+\omega_{t}$

ahol $x$ és $z$ a megfigyelhető, $\nu$ pedig a nem megfigyelhető (látens) változók vektora, míg a $T$ felső index a mátrix transzponáltját jelöli. A $\mu$ és az $\omega$ hibatagokról (pontosabban hibavektorokról) feltesszük, hogy nulla várható értékü, többdimenziós normális eloszlást követnek, és a két egyenlet hibatagjai egymással korrelálatlanok ( $Q$ és $R$ jelölik a $\mu$ és az $\omega$ kovarianciamátrixait): ${ }^{14}$

$\left[\begin{array}{l}\mu_{t} \\ \omega_{t}\end{array}\right] \sim N\left(\left[\begin{array}{l}0 \\ 0\end{array}\right],\left[\begin{array}{ll}Q & 0 \\ 0 & R\end{array}\right]\right)$.

Az olajpiaci sokkok makrogazdasági hatásainak vizsgálatakor az állapotegyenletek a konstans tagok és a parciális hatások időbeli alakulását foglalják magukban. Itt azzal a feltevéssel élünk, hogy a koefficiensek eltolás nélküli véletlen bolyongást követnek. Ennek megfelelően az állapotegyenletek:

$\delta_{t+1}=\delta_{t}+\gamma_{t+1}$

$\theta_{i t+1}=\theta_{i t}+\rho_{i t+1}$,

ahol $\gamma$ és $\rho_{i}$ nulla várható értékű gaussi fehér zajok $(i=0, \ldots, 12)$. Azaz a (8) egyenletben $\nu_{t}=\left[\begin{array}{lll}\delta_{t} & \theta_{0 t \ldots} & \theta_{12 t}\end{array}\right]^{T}$, az $F$ a $14 \times 14$-es identitásmátrix és $\mu_{t+1}=\left[\gamma_{t+1} \rho_{0 t+1} \ldots \rho_{12 t+1}\right]^{T}$.

${ }^{13}$ A Kalman-szűrő módszertanának részletes leírása megtalálható Hamilton [1994] 13. fejezetében. A paraméterek becslése rugalmas legkisebb négyzetek módszerével (flexible least squares, FLS) is lehetséges, de ahogy Montana és szerzőtársai [2009] megmutatta, a két eljárás majdnem ekvivalens. A módszertan hazai alkalmazásaihoz lásd Varga [2011], [2014], Darvas-Varga [2014].

${ }^{14}$ Bár a Kalman-szűrő egyik legkedvezőbb tulajdonságának a becslés robusztusságát szokták nevezni, az eloszlással kapcsolatos feltevések változtatása az eredményeket is módosítja. A témáról lásd bővebben Smith-Miller [1986], Meinhold-Singpurwalla [1989], Bradley és szerzőtársai [1992], illetve Naveau és szerzötársai [2005]. 
A megfigyelési egyenletek pedig (9) átírásából jönnek $z_{t}=\Delta y_{t}, H=\left[1 \hat{\xi}_{j t} \ldots \hat{\xi}_{j t-12}\right]^{T}$ és $\omega_{t}=u_{t}$ behelyettesítés mellett, a $G^{T} x_{t}$ tag elhagyásával:

$\Delta y_{t}=\delta_{t}+\sum_{i=0}^{12} \theta_{i t} \hat{\xi}_{j t-i}+u_{t}$.

Tehát a makrogazdasági hatások becsléséhez használt egyenletek annyiban módosulnak, hogy koefficienseik időben változnak, ugyanakkor a változás nem lehet túl nagy (a paraméterek csak kicsit mozdulhatnak el egyetlen negyedév alatt). A későbbiekben a modellből számított paraméterek simított (smoothed) verzióival dolgozunk, melyekből a sokkokhoz tartozó impulzusválasz-függvények fognak kirajzolódni.

\section{Az olajpiaci sokkok makrogazdasági hatásai}

Az 5. ábra a SVAR modellből származó impulzusválasz-függvényeket, illetve az ezekhez tartozó egy és két standard hibányi konfidencia-intervallumokat mutatja egyszórásnyi sokk mellett, a bekövetkezést követő két évben, havi bontásban. Az eredeti impulzusválasz-függvények némi módosításon estek át. Az olajkínálati sokkok esetén a szórás -1-szeresével (egy váratlan termeléskieséssel) dolgozunk, míg a termelésre vonatkozó hatásoknál az impulzusválasz-függvények kumulált alakja szerepel, így mindhárom változó szintben bekövetkező elmozdulásait tüntetjük fel.

A kínálati sokk termelésre vonatkozó hatása idővel gyengül, ami helyettesítésre utal, azaz más térségekben részben vagy egészben pótolják az így kiesett mennyiséget. A reálaktivitásra és az olaj reálárára vonatkozó hatás azonban nem szignifikáns, akár az egy, akár a két standard hibányi konfidencia-intervallumot tekintjük. Az eredményekből következik, hogy a vizsgált periódusban a nem várt termeléskiesés legfeljebb marginális hatással lehetett az olaj reálárára és a világgazdasági aktivitásra (legalábbis az átlagos hatást tekintve).

Ellenben egy aggregált keresleti sokk szignifikánsan növelte a reálárat (időben egyre magasabb szintre tornázva a kurzust), és a kitermelést is befolyásolta, bár utóbbi esetén a két standard hibányi konfidencia-intervallum használata mellett nem tapasztalunk nullától való szignifikáns eltérést. Ugyanakkor látható, hogy a pontbecslés szerint az első évben a kumulált hatás pozitív, és 7-10 hónappal a sokk bekövetkezése után enyhén szignifikáns, majd lassan a negatív tartományba bukik, és a 17. hónaptól kezdve ismét enyhén szignifikáns lesz. A kezdeti felívelő szakaszt alighanem a nyersanyag iránti növekvő kereslet okozza, az azonban nem egyértelmü, később mitől esik vissza a kínálat, miközben az árak tartósan magasak maradnak. Elképzelhető, hogy a megfejtést a kartellelméletben kell keresni, mivel Green-Porter [1984] eredményei szerint a körülmények változása a kartell viselkedését is módosítja, és „kedvező környezetben" (a kereslet dinamikus bővülésekor) könnyebb betartatni a szervezet szabályait, s az összprofitot maximalizáló stratégiát követni. Ez jelen esetben a kínálat visszafogását, az árak magas szinten történő stabilizálását jelentheti.

Egy olajspecifikus keresleti sokk az olajtermelést nem, míg a reálaktivitást csak az első néhány hónapban élénkíti, az olaj reálárát pedig a bekövetkezés utáni első 


\section{5. ábra}

Impulzusválasz-függvények egyszórásnyi sokk esetén, valamint az egy és két standard hibányi konfidencia-intervallumok (0-24 hónap)
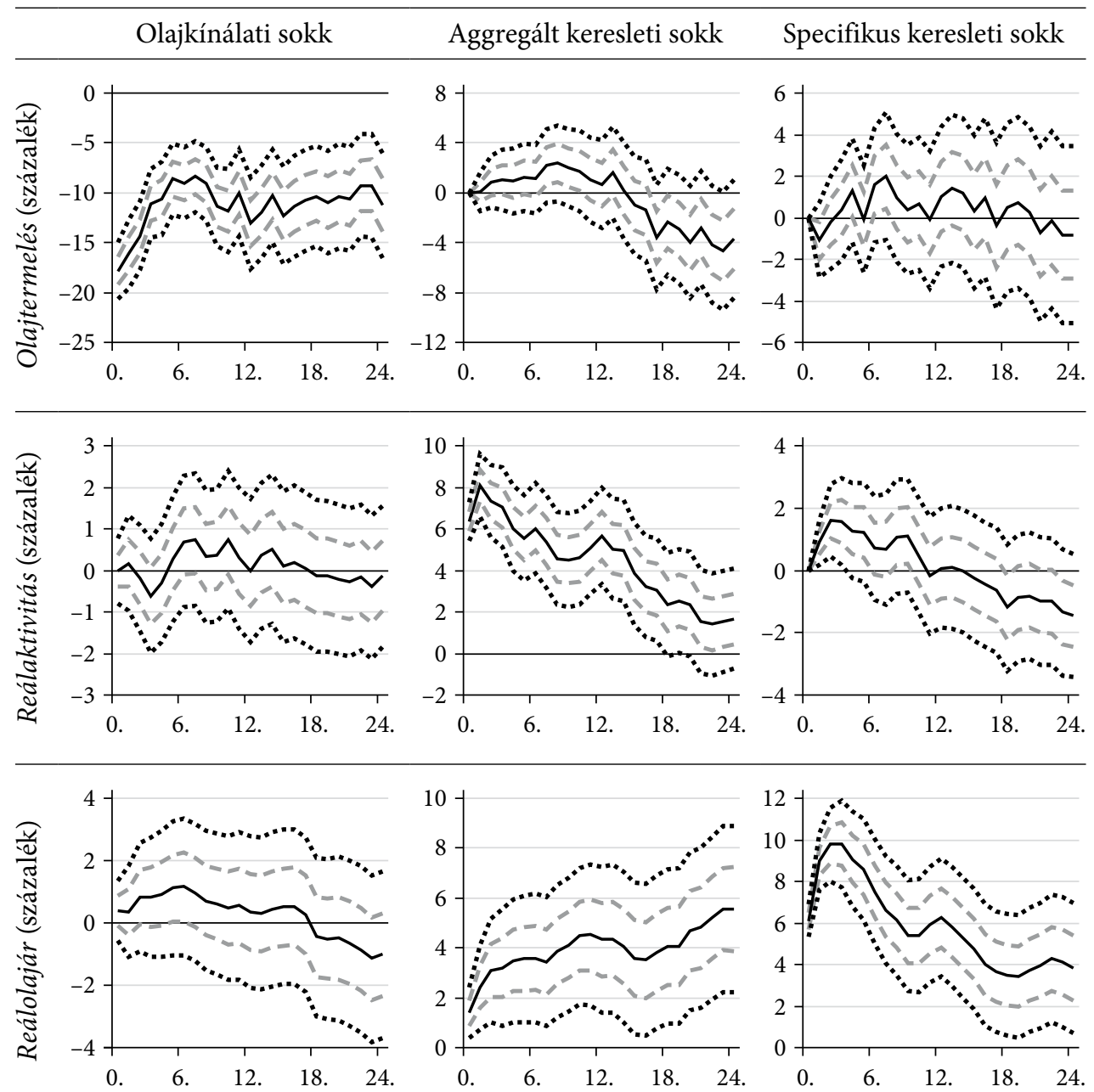

— Impulzusválasz-függvény

- - - Egy standard hibányi konfidencia-intervallum Két standard hibányi konfidencia-intervallum

Forrás: saját szerkesztés.

hónapokban emeli meg a legjobban, utána az alappályától vett eltérés folyamatosan csökken, ellentétben az aggregált keresleti sokknál megfigyelt esettel. Ez arra utal, hogy a kínálat csökkenésének veszélye ritkán tartós, és az elővigyázatossági vásárlások felfutását jellemzően az árak gyors normalizálódása követi.

A SVAR-eredmények ismeretében kiszámolható, hogy a sokkok milyen mértékben járultak hozzá az olaj reálárának alakulásához az elmúlt évtizedekben (6. ábra). A 6. ábrán a függőleges tengely a sokkoknak $100 \times \ln$ (olajreálár)-hoz való hozzájárulását méri. 
6. ábra

A sokkok kumulatív hatása az olaj reálárára (havi bontás, 1975. január-2014. december)

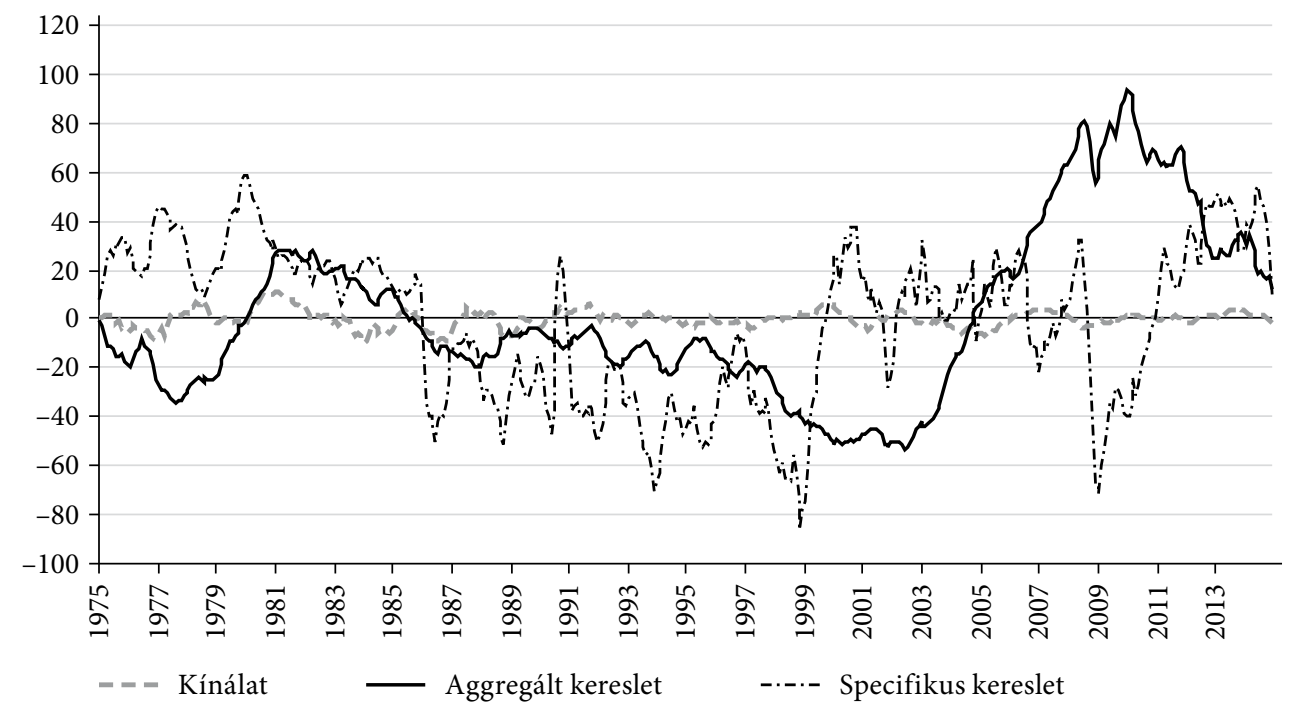

Megjegyzés: a reálolajár logaritmusához való hozzájárulás a SVAR modellszámítások alapján. Forrás: saját szerkesztés.

A 6. ábrából kitűnik, hogy a vizsgálati periódus alatt az olajkínálati sokkok érdemben nem módosították az árat (összhangban az 5. ábrán látható impulzusválaszfüggvénnyel), ellenben a keresleti sokkok erös befolyást gyakoroltak rá. 1975-től 1979-ig a globális gazdasági lassulás miatt a reálaktivitást érö sokkok összességében csökkentették az olaj reálárát, ugyanakkor látható, hogy már 1977-től kezdve megfordult a trend, az élénkülö kereslet pedig elkezdte ledolgozni a korábbi mínuszokat. Ebben az időszakban a specifikus keresleti sokkok is hozzájárultak a magas árakhoz, ezek azonban rövid periódusok voltak, és az 1980-as csúcs (az iráni forradalom és az afganisztáni szovjet beavatkozás) után folyamatosan csökkent a szerepük. Ezután majd másfél évtizeden át a specifikus sokkok hozzájárulása negatív volt, csupán néhány kivételes esemény okozott nagyobb kilengéseket. Ilyen volt az első Öböl-háború, amikor a biztonsági készletezés révén pozitív specifikus keresleti sokkhatás érte a piacot, ez azonban a geopolitikai feszültség enyhülése után azonnal megszűnt. Igazi változást a 2000-es évek elejétöl, nagyjából 2002-től tapasztalunk, amikor az aggregált keresleti sokkok egészen 2008-ig folyamatosan emelték az olaj reálárát, és csak a válság után, 2010 közepétől fejtettek ki negatív hatást, ami egészen a mintaidőszak végéig kitartott.

Ezzel némileg ellentétesen mozgott a specifikus keresleti sokkok kumulatív hatása. A modell szerint ez okozta a pénzügyi/világgazdasági válság során megfigyelt hirtelen áresést, majd támogatta az árak korrekcióját a magasabb tartományokba, ezzel ellentételezve a reálaktivitást érő negatív innovációk hatását, egészen 2014 második feléig. Ekkor a megfigyelt áresés döntő hányada már közvetlenül az olajpiacot érintő sokkok következménye volt. Ez a megfigyelés elsőre talán ellentmondásosnak tűnik, mivel a kezdeti árcsökkenést inkább a válság okozta recesszióval, a visszapattanást az 
abból történő kilábalással, azaz aggregált keresleti sokkokkal, míg az utolsó hónapok zuhanását kínálati elemekkel (amerikai palaolaj-termelés felfutása, az OPEC stratégiaváltása) magyaráznánk.

A modell eredményei azonban rávilágítanak e hipotézis helytelenségére. Jól látható ugyanis, hogy a reálaktivitás kumulatív hatása a teljes mintán lassan, egyenletesen változott, miközben a specifikus kereslet hozzájárulása akár néhány hónap alatt nagy elmozdulásokat tudott produkálni. Az olajárba gyorsan beépülnek az információk: a rossz makrogazdasági kilátások önmagukban elegek ahhoz, hogy lenyomják a határidős árakat, onnan pedig a csökkenés átgyürüzik az azonnali piacokra (illetve a rövid lejáratú szállítások díjszabásába). Így az olajár 2008-2009 során tapasztalt visszaesése csak részben tekinthető az akkor már lassuló globális növekedés következményének, azt jórészt a kilátások romlása, a jövőbeli kereslet csökkenése okozta, mégpedig a biztonsági jellegű vásárlások mérséklődésén keresztül. Amikor elkezdődött a válságból való kilábalás, az emelkedő árakra vonatkozó várakozások és az arab tavasz eseményei pozitív specifikus keresleti sokkokat generáltak, amelyek a hosszú távú trend alá bukó reálaktivitás negatív hatását ellensúlyozva elérték, hogy az olajár visszaemelkedjen a korábbi szintek közelébe. Ezt az ellátási bizonytalanságot törte meg, amikor a nem konvencionális kitermelés volumene az OPEC fontosabb szereplöit, elsősorban Szaúd-Arábiát piaci részesedésük megtartására, kitermelésük növelésére ösztönözte.

A modellből nyert sokkváltozók idősorai már alkalmasak a makrogazdasági hatások elemzésére. Az impulzusválasz-függvény minden esetben az egyenletek becsült paramétereinek sorozata, aminek kumulált változata adja a szintben bekövetkezett változásokat. A könnyebb értelmezhetőség kedvéért olajkínálati sokkon ezúttal is a termelés visszaesését értjük. Az eredményeket a 7. ábra foglalja össze, minden blokkban az oszlop szerinti sokk egységnyi változásának az adott makrogazdasági változóra (CPI, GDP-deflátor, GDP, munkanélküliségi ráta) vonatkozó hatása (az alappályától vett százalékos, munkanélküliségi ráta esetén százalékpontos eltérése), valamint a kumulált impulzusválasz-függvényhez tartozó egy és két standard hibányi konfidencia-intervallumok szerepelnek a sokk bekövetkezése óta eltelt idő függvényében.

Két standard hibányi konfidencia-intervallum használata mellett arra a megállapításra jutunk, hogy egy kínálati sokk csupán a munkanélküliségi rátát képes szignifikánsan megemelni, azt is csak a bekövetkezés után 1-3 negyedévvel. Amenynyiben a megengedőbb egy standard hibányi konfidencia-intervallumot tekintjük, akkor a munkanélküliséget növelö hatás a három év alatt végig kitart, és egy rövid ideig tartó gazdasági visszaeséssel ( 0 -2. negyedévben a GDP szignifikánsan az alappálya alá bukik), illetve némi inflációval párosul. Utóbbi kapcsán érdemes megjegyezni, hogy míg a fogyasztói árindex (CPI) alappályától vett eltérése nagyjából a bekövetkezés után hat negyedévvel válik nem szignifikánssá, addig ugyanehhez a GDP-deflátornak tíz negyedévre van szüksége. A maximális eltérés a sokk bekövetkezése után 1-1,5 évvel alakul ki, onnantól kezdve mind a CPI, mind a GDPdeflátor pontbecslése kiigazít. Az egy standard hiba használata melletti elemzés persze nem feltétlenül meggyőző.

Perotti [2012] más munkák kapcsán megjegyzi, hogy a közgazdasági alkalmazásokban talán csak azért terjedt el ennyire az egy standard hibányi konfidencia- 
7. ábra

A sokkok kumulált hatása az Egyesült Államok makrogazdasági mutatóira (0-12 negyedév)

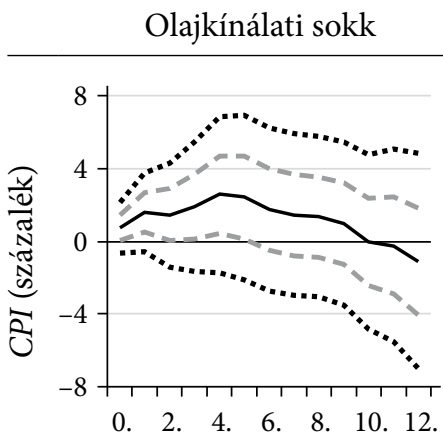

Aggregált keresleti sokk
Specifikus keresleti sokk
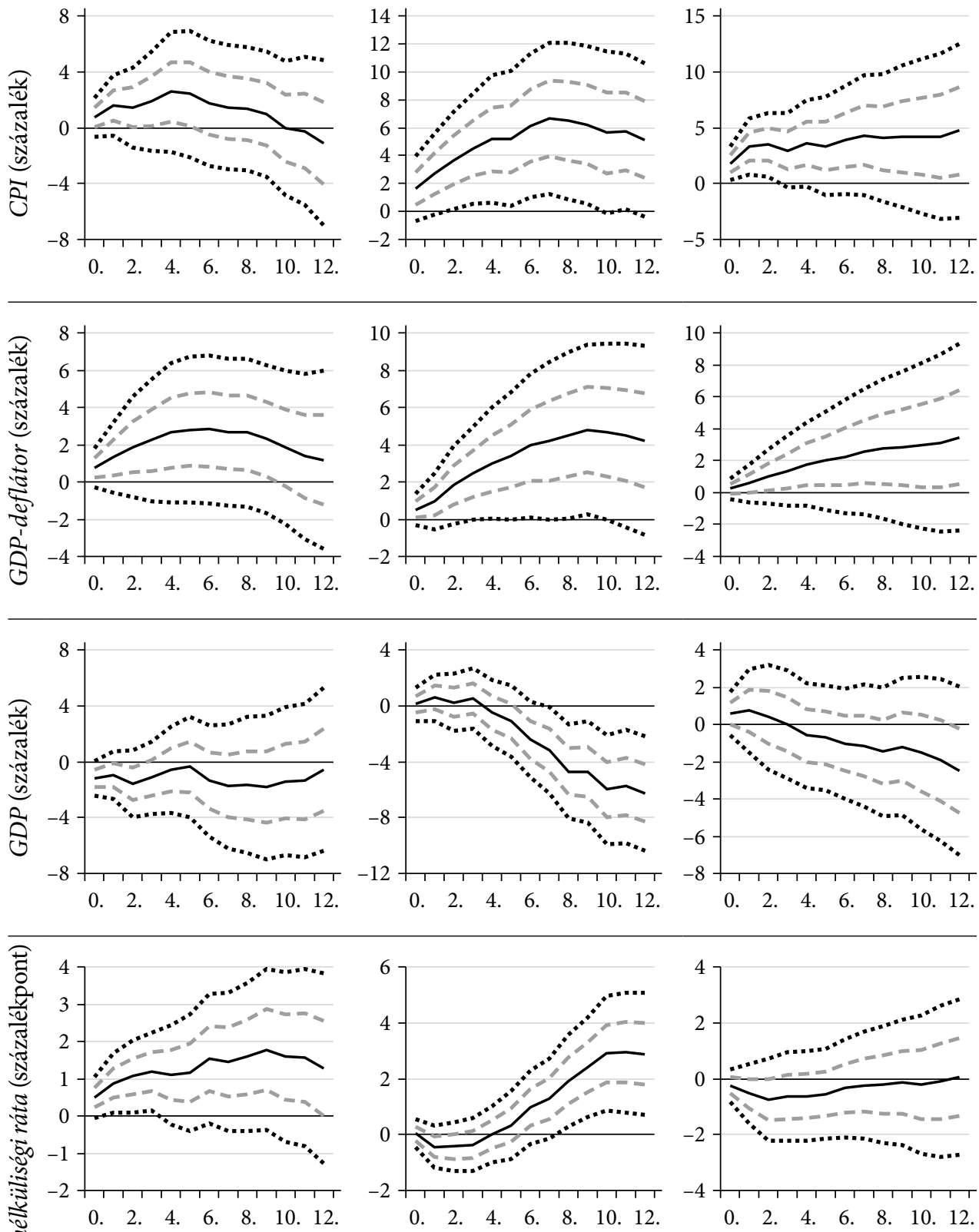
intervallum használata, mert két standard hiba mellett a levont konklúziók jelentős hányada már érvényét vesztené. Összességében tehát nincs meggyőző bizonyíték arra, hogy az Egyesült Államokban az olajkínálati sokkoknak komoly recessziós és inflációs hatásuk lett volna az elmúlt évtizedekben, egyedül a munkanélküliségi rátánál tapasztalni egy rövid ideig tartó szignifikáns emelkedést. Ugyanakkor a módszertani részben kifejtett problémák miatt a kínálati sokkok esetében endogenitási probléma léphet fel, így a konklúziókat is fenntartással kell kezelni.

Az aggregált keresleti sokk ezzel szemben már mind a négy makrováltozó esetén szignifikáns eltérést okoz a sokk nélküli esethez képest. Az árindexek folyamatosan emelkedve, nagyságrendileg másfél-két év után érik el a maximális különbséget, majd utána enyhén korrigálnak. Egy standard hibányi konfidencia-intervallum mellett az eltérés a három év egészében szignifikáns, és CPI esetén a sokk bekövetkezése után 2-9 negyedévvel még két standard hiba mellett is az marad.

A GDP-deflátornál a vízszintes tengely a konfidencia-intervallum határán helyezkedik el, azaz ekkor is van némi statisztikailag kimutatható inflációs hatás. Ennek oka, hogy az aggregált keresleti sokk az olaj árát tartósan emeli (5. ábra), illetve egyéb nyersanyagoknál is drágulás figyelhető meg, ami az amerikai árindexek növekedésével jár. Ez idővel a reálgazdasági mutatókat is negatívan érinti, ám kezdetben e hatás nem érvényesül. Az első negyedévekben a pontbecslés még a GDP növekedését, a munkanélküliség esését jelzi (bár szignifikáns eltérésről itt nem beszélhetünk), valamikor a második év során azonban a magasan ragadt nyersanyag árak negatív hatása kezd dominálni, és az alappályához képest tartósan magasabb munkanélküliségre és alacsonyabb GDP-re lehet számítani. Kilian [2010] erre a dinamikára utalva állította, hogy (Hamilton [2009] eredményeivel összhangban) a magas olajárak végül is hozzájárultak a recesszió kialakulásához, mivel a 2003-2008 közötti áremelkedést okozó, folyamatosan jelentkező aggregált keresleti sokkok pozitív rövid távú hatása egy darabig segítette a gyors gazdasági növekedés fennmaradását, azonban a sokkok megszünésével ez az ellensúly megszünt, és így a hosszabb távú negatív hatás érvényesülni tudott.

$\mathrm{Az}$ 5. ábrán látható volt, hogy egy specifikus keresleti sokk az olaj reálárára az első negyedévekben fejti ki a legnagyobb hatást. Ennek következtében a fogyasztói árindexet is csak a bekövetkezés után fél évig tudja szignifikánsan az alappálya fölé lökni, míg a GDP-deflátornál az eltérés statisztikailag nem különbözik nullától. ${ }^{15}$ A reálgazdasági változóknál nincs recesszióra utaló jel. Ez azt sugallja, hogy a 2008-2009-es válságból való kilábalás alatt az Egyesült Államok gazdaságát nem hátráltatta a specifikus sokkok miatti olajár-emelkedés. Söt, ha csak a pontbecslést nézzük, akár még hozzá is járulhatott a munkanélküliség csökkenéséhez. Ezt magyarázhatja az amerikai olajtermelés felfutása (Feyrer és szerzőtársai [2015]), azonban meg kell jegyeznünk, hogy az impulzusválasz-függvény a teljes mintaidöszakra jellemzö átlagos értéket mutatja, míg a palaolaj-forradalom csak az utóbbi öt évben vált meghatározóvá.

\footnotetext{
${ }^{15}$ Egy standard hibányi konfidencia-intervallum használata mellett már a vizsgált három év egésze alatt kimutatható a különbség.
} 


\section{A makrogazdasági hatások időbeli változása}

A Kalman-szűrős modellből nyert eredményeket a Függelék F1-F3. ábrái tartalmazzák. Minden esetben az ábracímben megjelölt, egységnyi nagyságú sokkhoz tartozó kumulált impulzusválasz-függvényeket ábrázoltuk, azaz a makrogazdasági változó szintjében bekövetkezett változást, az alappályától (a sokk nélküli esettől) való százalékos (munkanélküliségi ráta esetében százalékpontos) eltérést. Továbbra is igaz, hogy a kínálati sokknál egy nem várt termeléskiesés hatása szerepel. Mindhárom ábra azonos struktúrát követ. Az első oszlopban az egységnyi sokk adott makrováltozó (CPI, GDP-deflátor, GDP, munkanélküliségi ráta) szintjére gyakorolt hatása szerepel három évre előre, negyedéves bontásban, öt különböző időpontban, azaz attól függően, hogy a nem várt változás mikor következett be. A vizsgált negyedévek a következők: 1978. I. negyedév, 1987. IV. negyedév, 1996. IV. negyedév, 2005. IV. negyedév, 2014. IV. negyedév. A második oszlopban szintén a kumulált impulzusválasz-függvények szerepelnek, de már egy másik nézőpontból: egységnyi sokknak milyen hatása volt az adott változó szintjére 0, 1, 2 és 3 évvel a bekövetkezése után, attól függően, hogy ez a sokk melyik negyedévben (vízszintes tengely) következett be. A becslés során az egy és két standard hibányi konfidencia-intervallumokat is kiszámítottuk, amelyek a szignifikáns hatásról adnak információt. A Függelékbeli ábrák harmadik oszlopában található hőtérképek e szignifikanciapróbák eredményeit sủrítik grafikus formába. A vízszintes tengelyen a sokk bekövetkezésének időpontja szerepel, míg a függőleges tengely rögzített, mindig 0-12 negyedévet jelöl. A hőtérkép gyakorlatilag egy mátrix, aminek $(i ; j)$ eleme azt mutatja, hogy a j-edik negyedévben bekövetkező sokk hatása szignifikáns-e $i$ negyedévvel a bekövetkezés után (az ábrán a legfelső sorban a 12 negyedévvel későbbi hatás szerepel, míg az azonnali hatáshoz az alsó sor tartozik). Ha a hatás a két standard hibányi konfidencia-intervallum mellett is szignifikáns, akkor a mező fekete, ha csak egy standard hiba mellett tekinthető statisztikailag nullától különbözőnek, akkor szürke, minden egyéb esetben (tehát amikor a hatás nem szignifikáns) fehér.

\section{Kinálati sokk}

Kínálati sokkok tekintetében az eredmények vegyesek (F1.ábra). Az inflációs mutatóknál szinte sohasem találunk szignifikáns hatást. Ez alól a fogyasztói árindex esetében a legutóbbi pénzügyi, gazdasági válság jelent kivételt, ahol majdnem a teljes hároméves horizonton statisztikailag kimutatható az összefüggés, igaz, ahogy az első sor második oszlopában található grafikonról leolvasható, a modell szerint ekkor kifejezetten dezinflációs hatása volt egy nem várt kiesésnek. Mivel a későbbiekben ez a szignifikancia teljesen eltünt, nem zárható ki, hogy csak átmeneti jelenségröl volt szó, amit a válság okozta zaj számlájára írhatunk, és amit az alkalmazott módszertan nem tudott megfelelöen kezelni.

A GDP-deflátornál ez a kiugrás már nem jelenik meg, bár itt nagyjából 2000től kezdve enyhén szignifikáns eredményeket kapunk, legalábbis a sokkot követő 
1-2 negyedév távlatában, ami némi inflációs nyomás kialakulására, majd gyors lecsengésére utal.

A GDP szintjére egy kínálati sokknak maximum fél évig volt szignifikáns befolyása, ennél hosszabb időtávon legfeljebb 1980 körül lehetett némi hatása, ami azonban egyszeri kiugrásnak tekinthető. A 0-2 negyedéves időtávon nincs egyértelmü trend, a szignifikanciaszint hol erösödött, hol gyengült, a pontbecslés pedig a negatív tartományokban mozgott.

A nem várt kiesések hatása tehát sem a vizsgált árindexek, sem a GDP esetében nem mutat egyértelmủ időbeli változást, vagy ha igen, akkor az nem tünik trendszerủ elmozdulásnak. Ezzel szemben az amerikai munkanélküliségi ráta egyre erösebben reagál a kínálati sokkokra, ami mind a pontbecslésben, mind annak szignifikanciaszintjében megjelenik. Blanchard-Galí [2007] szerint a rugalmasabb munkaerőpiac segít tompítani az olajár növekedésének negatív hatásait, amiből az következne, hogy a foglalkoztatás - legalábbis hosszú távon - kevésbé érzi meg a külső sokkokat, itt azonban nem ezt látjuk.

Ez pedig rá is mutat a módszertan egyik hiányosságára. Egy kínálati sokk nem tekinthető homogénnak, a forrás lehet az OPEC-en belül és kívül, vagy ami jelen esetben még fontosabb, az Egyesült Államokon belül és kívül. Nyilvánvaló, hogy a palaolaj-termelés felfutása nem ugyanazt jelenti az amerikai munkaerőpiacnak, mint a szaúdiak termelésbővítése, pedig a metodológia szerint mindkettő ugyanolyan kínálati sokknak számít. Azonban míg utóbbi legfeljebb az olcsóbb olajon és a monarchia amerikai termékek iránti megnövekedett keresletén keresztül fejthet ki hatást, addig előbbi közvetlenül érinti az Egyesült Államok olajiparának és beszállítóinak munkavállalóit, az adóbevételeket, beruházásokat, jövedelmeket stb. Így akár az is elöfordulhat, hogy egy nem várt kiesés munkanélküliségre való hatásának előjele attól függ, hol következik be a kínálati sokk. Ha az Egyesült Államokban, az rontja az ottani olajipar és a beszállító ágazatok pozícióit, míg ha külföldön, akkor az amerikai kitermelök még profitálhatnak is a nyersanyag drágulásából. Továbbfejtve Kilian [2009] „nem minden olajársokk egyforma” megállapítását, azt mondhatjuk, hogy nem minden kínálati/keresleti sokk egyforma, és bizonyos esetekben szükség lehet az itt használt felbontásnál is mélyebbre ásni (lásd Bodenstein és szerzötársai [2012]).

\section{Aggregált keresleti sokk}

A világpiaci reálaktivitás váratlan élénkülése az 1970-es és 1980-as években a későbbieknél jóval erősebb, gyakran enyhén szignifikáns hatást fejtett ki a fogyasztói árszintre, ráadásul ez a hatás sokszor tartósnak bizonyult, a sokk után három évvel is kimutatható maradt (F2. ábra). Ez az inflációs nyomás azonban az 1990-es évek elején gyakorlatilag teljesen megszűnt, és bár a válság során látszólag újra megjelent, a korábbiakhoz hasonlóan itt is csak átmeneti jelenségnek bizonyult, jó eséllyel nem valós összefüggésről, csupán modellezési problémáról van szó. Ezzel szemben az GDP-deflátornál ezúttal sem tapasztalni ilyen jellegü kiugrást, és a becslési eredmények arra engednek következtetni, hogy bár a GDP-deflátor szintjében egy aggregált 
keresleti sokk szignifikáns emelkedést okoz, az eltérés volumene az évtizedek során trendszerüen csökkent, az utolsó években már csak a bekövetkezés utáni 2 . negyedévtől kezdve szignifikáns némileg az összefüggés (amennyiben az egy standard hibányi konfidencia-intervallummal dolgozunk). A reálolajár 2000-es években tapasztalt emelkedése során tehát nemcsak azért sikerült elkerülni a pénzromlás ütemének gyorsulását, mert az áremelkedés mögött az aggregált keresleti sokkok felfutása, az ázsiai növekedés beindulása állt, hanem azért is, mert annak árindexekre gyakorolt hatása az évtizedek folyamán sokat gyengült.

Hasonló megállapításra jutunk a reálgazdasági hatásokat illetően is. Bár a GDP esetében nem trendszerü gyengülés, inkább folyamatos hullámzás jellemzi az idősort, a pontbecslések szerint épp a 2000-es években - a válság rövid időszakát leszámítva - meglehetősen enyhe és nem szignifikáns volt az alappályától való eltérés. Meg kell jegyeznünk, hogy az eredmények alapján ezt megelözően sem igazán volt szignifikáns a hatás. Az utóbbi években ugyanakkor ismét erősödtek az aggregált keresleti sokkok negatív következményei, de csak újabb adatok beérkezése után lehet majd eldönteni, hogy ez valamiféle trend kezdete vagy a korábbi hullámzás folytatódása.

A munkanélküliségi ráta esetében már sokkal inkább egyértelmü, hogy a globális kereslet nem várt emelkedése egyre kevésbé érinti a változó pályáját. A kumulált impulzusválasz-függvények szerint a sokk bekövetkezése utáni 0,5-3 évben a munkanélküliségi ráta annál kisebb mértékben emelkedett, minél később történt a váratlan esemény. A sokk utáni első fél/háromnegyed évben ráadásul az egy standard hibányi konfidencia-intervallum szerint még szignifikáns csökkenés is történik. Ennek oka, hogy bár a nyersanyagok iránti kereslet élénkülése emeli az amerikai importkiadásokat, azonban a világgazdasági élénkülés kezdetben ellensúlyozza ennek negatív hatásait, ahogy azt már az időben változatlan paraméterü modellnél is megállapítottuk.

Így összességében elmondható, hogy az aggregált keresleti sokkok árindexnövelő hatása jelentősen gyengült az elmúlt évtizedek folyamán, a GDP esetében a befolyás mértéke hol gyengébb, hol erősebb volt, de épp a 2000-2010-es időszakban nem volt szignifikáns, míg a munkaerőpiac ellenálló képessége az egész mintaidőszak alatt javuló tendenciát mutatott. Ez arra enged következtetni, hogy a 2000-es években a stagfláció elmaradása részben a sokkok összetételének, részben az olajár emelkedését okozó sokktípus gyengülő makrogazdasági hatásainak volt köszönhető.

\section{Specifikus keresleti sokk}

A biztonsági vásárlásokkal összefüggő specifikus keresleti sokkok makrogazdasági hatásainál is azt találjuk, hogy az évtizedek folyamán komolyan megváltoztak. Ez azért különösen érdekes, mert az olajár válság utáni újbóli megemelkedésében, valamint a 2014 második felében indult áresésben is e sokkok voltak meghatározók (6. $a ́ b r a)$. Így vizsgálatukkal képet nyerhetünk arról, milyen szerepet játszott a magas olajár a válságból való kilábalás során, illetve milyen makrogazdasági következményekkel járhat a legutóbbi árzuhanás. Az eredményeket az F3. ábra foglalja össze. 
Az amerikai fogyasztói árindex az évtizedek alatt egyre ellenállóbb lett a specifikus keresleti sokkokkal és az általuk kiváltott átmeneti olajár-emelkedéssel szemben. Az 1980-as években volt a legnagyobb és leginkább szignifikáns az alappályától való eltérés, majd folyamatos csökkenés után a 2000 -es évek közepére szinte teljesen megszünt. Az enyhülés a sokk bekövetkezése utáni három év egészében megfigyelhető: a kumulált impulzusválasz-függvény minden horizonton a vízszintes tengelyhez közelített. Ezt követően azonban hirtelen visszarendezödés történt, és bár a pénzügyi, gazdasági válság lecsendesedése után némi enyhülést figyelhetünk meg, napjainkban ismét az 1980-as évekhez hasonló erösségü és szignifikanciájú hatás jellemző.

Míg a kínálati és az aggregált keresleti sokkok esetén lehetett a válság okozta zajjal magyarázni a történteket, hasonló okfejtés itt már aligha állná meg a helyét, hiszen nem tapasztalunk kellő mértékű korrekciót. Egy lehetséges magyarázat szerint az olajspecifikus keresleti sokkok az olajáron keresztül az amerikai olajszektorra pozitív hatást fejtenek ki, a megnövekedett jövedelem pedig élénkíti az Egyesült Államok aggregált keresletét, ezáltal emeli az árszínvonalat. Kérdéses persze, hogy az egyéb ágazatokat érintő többletteher nem ellensúlyozza-e ezt a hatást.

Természetesen továbbra is lehetséges, hogy csupán a rossz modellspecifikáció okozza ezt a dinamikát, és részletesebb bontásra, valamint más magyarázó változók (például a Fed monetáris politikájának) figyelembevételére lenne szükség. Mindenesetre az eredmények azt sugallják, hogy a 2014-ben esésnek indult olajár legalább rövid távon (az első fél évben) szignifikáns dezinflációs hatást fejtett ki.

Egységnyi specifikus sokk a bekövetkezés után 2-4 negyedévvel szignifikánsan növelte a GDP-deflátor szintjét, függetlenül attól, hogy az elmúlt 40 év során mikor következett be. A modellbecslés szerint a hatás volumene is változatlan volt az évtizedek alatt. Egy éven túl azonban jól látható, hogy az alappályától vett differencia jelentősen szükült, a minta végén két éven túl már semmiféle szignifikáns hatás nem mutatható ki, és 1-2 éves távlatban is csupán az egy standard hibányi konfidencia-intervallum mellett tekinthetjük statisztikailag nullától különbözönek a kumulált hatást. Így a fogyasztói árindexhez hasonlóan itt is elmondhatjuk, hogy a mintaidőszak végére jellemző negatív specifikus sokkok ugyan negatívan hatnak a GDP-deflátor nagyságára, ez azonban átmeneti jelenség, nagyjából 1-2 év elteltével teljesen eltünik.

A GDP esetében meglehetősen vegyes eredmények születtek, ugyanakkor a tesztek alapján legfeljebb a minta második felében, a sokk bekövetkezése után 0-1 negyedévvel van szignifkáns hatása egy specifikus keresleti sokknak (ez azonban csak az egy standard hibányi konfidencia-intervallum használata mellett igaz). Meglepő módon a pontbecslés ekkor enyhén pozitív elmozdulást jelez, azaz a biztonsági vásárlások felfutása inkább élénkíti, nem pedig csökkenti a GDP-t. A kumulált impulzusválasz-függvények 0 és 1 negyedév esetén pedig trendszerü emelkedést mutatnak, ami a hatás erősödését jelenti (az F3. ábrán csak az azonnali hatás időbeli változása szerepel, de az 1 negyedéves érték is hasonló dinamikát mutat). Ezt a trendet a jövőben tovább erősítheti az amerikai gazdaság strukturális változása, az olajszektor növekvő fontossága. Az eredmények egyben arra is 
rámutatnak, hogy az olajár mintaidőszak végén tapasztalt csökkenéséből az amerikai gazdaság nem feltétlenül tudott profitálni.

A munkanélküliségi rátánál ezúttal is a sokkhatás egyértelmü csökkenését tapasztaljuk. A biztonsági vásárlások okozta áremelkedés egyre kevésbé járt együtt a munkanélküliség növekedésével, és a mintaidőszak végére $0-2$ negyedéves távlatban enyhén szignifikáns és negatív hatást fejtett ki a mutató értékére, ezzel ismét az amerikai olajszektor fontosságára hívva fel a figyelmet.

Összességében elmondható, hogy a specifikus keresleti sokkok hatása időben jelentősen megváltozott, és az eredmények azt sugallják, hogy a 2008-as válság utáni kilábalás alatt nem hátráltatták, inkább segítették az amerikai gazdaságot a növekedés gyorsításán és a munkanélküliség mérséklésén keresztül. A 2014-ben indult maszszív áresés azonban kedvezőtlenül érinthette az Egyesült Államok reálgazdaságát, bár a hatás csak rövid ideig, legfeljebb 1-2 negyedéven át tekinthető szignifikánsnak.

\section{Robusztussági vizsgálatok}

A kapott eredmények robusztusságának vizsgálatára alternatív modellspecifikációk mellett is megbecsültük a sokkok makrogazdasági hatásainak időbeli változását. Ehhez három megközelítést használtunk. Egyrészt Kilian [2009] módszerét a minta első és második felére külön-külön megismételtük, majd összehasonlítottuk az ebből nyert impulzusválasz-függvényeket. Másrészt előállítottunk időben változó paramétereket a Kalman-szürőnél jóval egyszerübb eljárással is. Ekkor azt feltételeztük, hogy a makrogazdasági változókra felírt egyenletekben a koefficiensek lineáris trendet követnek, magukat a paramétereket pedig OLS-sel becsültük a Newey-West-féle autokorreláció és heteroszkedaszticitás robusztus standard hibák használatával. ${ }^{16}$

Végül módosítottuk a Kalman-szürővel végzett elemzést, a függő változó utolsó négy negyedévnyi értékének bevonásával bővítettük az egyenleteket. Mindhárom esetben a kumulált impulzusválasz-függvényeket, azaz a változók (fogyasztói árindex, GDP-deflátor, GDP, munkanélküliségi ráta) szintjében bekövetkező változásokat vizsgáltuk. A fö következtetés továbbra is érvényes: az alternatív megközelítések mellett is igaznak bizonyult, hogy a különböző sokkok makrogazdasági hatásai eltérnek egymástól, valamint az, hogy ezek a hatások az elmúlt évtizedekben akár jelentősen módosulhattak is.

Természetesen akadtak különbségek. A Kilian [2009]-féle elemzés részmintákon történő megismétlése arra utal, hogy a kínálati sokkok GDP-re gyakorolt negatív hatása némileg erösebb lehetett a mintaidőszak második felében, bár ezt egyetlen más modell sem erősítette meg. A függő változó késleltetett értékeinek bevonásával készült Kalman-szürös becslés pedig azt mutatja, hogy a specifikus keresleti sokkok munkanélküliségi rátára vonatkozó hatása ugyan sokat enyhült, ám a mintaidőszak végén is a pozitív tartományban mozgott (bár statisztikailag nem különbözött nullától). Ez

\footnotetext{
${ }^{16}$ Ez továbbra sem kezeli a generált regresszorok problémáját.
} 
árnyalja az alapmodell eredményeit, és arra enged következtetni, hogy az olajár 2008 utáni mozgásának domináns elemévé elölépett specifikus keresleti sokkok mégsem segítették a válságból való kilábalást, 2014-ben pedig nem lassították a munkaerőpiaci helyzet javulását. Itt is igaz azonban, hogy a többi modell inkább alátámasztja, nem pedig cáfolja az eredeti megállapításokat.

\section{Következtetések}

A tanulmány időben változó paraméterü ökonometriai modellek segítségével vizsgálta, mi okozza az olajár gyengülö makrogazdasági hatásait. Míg Blanchard-Galí [2007] a gazdaság strukturális változásaira, jobb ellenálló képességére vezette viszsza a mérsékeltebb károkat, addig Kilian [2010] megmutatta, hogy a makrogazdasági hatások függnek az árváltozás szerkezeti összetételétől, és e mögöttes faktorok miatt tünik úgy, hogy az Egyesült Államok növekedési és inflációs mutatói ma már kevésbé érzékenyek az olajár emelkedésére, mint voltak az 1970-es vagy az 1980-as években. Ugyanakkor a két elmélet nem zárja ki egymást, és az itt bemutatott eredmények azt igazolják, hogy nem csupán az olajár-emelkedés strukturális összetevői változtak az évtizedek folyamán, de az Egyesült Államok gazdasága is másképp reagál e tényezőkre, mint 30-40 évvel ezelött. Bár ebből még nem következik, hogy épp a Blanchard-Galí [2007] által megjelölt tényezők okozzák az ellenálló képesség növekedését, mindenesetre potenciális jelölteknek tekinthetők.

A tanulmányban bemutatott eljárások fejlesztésére, a kutatás továbbvitelére számos lehetőség kínálkozik. A VAR modellben szereplő változók alternatív transzformációinak használata, vagy akár új változók bevonása teheti teljesebbé az elemzést. Ugyanígy hasznos lehet a bemutatott modelleket más makrováltozókra (ipari termelés, maginfláció stb.), illetve országokra kiterjeszteni, valamint a felírt modellek módosítása révén az eredményeket újabb robusztussági vizsgálatoknak alávetni. Érdekes irány lehet az exportőr és importőr országok közti különbségek feltárása, valamint annak eldöntése, mely strukturális jellemzők határozzák meg az olajár változásával szembeni „rezisztencia” mértékét. Érdemes külön vizsgálni, mennyire tekinthető stabilnak a VAR alapján felírt kapcsolat. A dolgozat alapötlete épp az volt, hogy a sokkok makrogazdasági hatásai időben változnak, ez pedig igaz lehet magára az olajpiacra is. Elég csak az amerikai palaolaj-termelés felfutására gondolni, ami az elmúlt években alapjaiban változtatta meg a piac szerkezetét, és kulcsszerepe volt az OPEC-en belüli kooperáció gyengülésében. Ezt a kérdést időben változó paraméterü VAR modellekkel lehetne megközelíteni.

A mögöttes folyamatok jobb megértéséhez elméleti modellek építésével juthatunk. Egy ilyen keretben célzottan vizsgálhatóak olyan, itt empirikusan nem tárgyalt kérdések, mint a makrogazdasági hatások aszimmetriája, a sokkok finomabb felbontása, ${ }^{17}$

\footnotetext{
${ }^{17}$ A sokktípusok körének bővítése azért is célszerű, mert ahogy az eredményekből kiderült, bizonyos esetekben túlzott aggregációt hajtunk végre. Nem mindegy például, hogy a kitermelési volumen emelkedése a Közel-Keleten vagy Észak-Amerikában történik.
} 
a gazdaságpolitikai reakciók szerepe, az erőforrás raktározhatóságából eredő dinamikus döntési probléma, a spekulatív kereslet jelenléte, az olaj és más nyersanyagpiacok közti kölcsönhatás, valamint a nem tökéletes verseny és a piacszerkezet időbeli alakulásának következményei.

\section{Hivatkozások}

Anzuini, A.-Pagano, P.-Pisani, M. [2014]: Macroeconomic effects of precautionary demand for oil. Journal of Applied Econometrics, Vol. 30. No. 6. 968-986. o. http://dx.doi. org/10.1002/jae.2419.

Atkeson, A.-Kehoe, P. J. [1999]: Models of Energy Use: Putty-Putty Versus Putty-Clay. American Economic Review, Vol. 89. No. 4. 1028-1043. o. http://dx.doi.org/10.1257/ aer.89.4.1028.

Barsky, R. B.-Kilian, L. [2001]: Do We Really Know that Oil Caused the Great Stagflation? A Monetary Alternative. Megjelent: NBER Macroeconomics Annual, 2001. Vol. 16. No. 1. 137-183. o. http://www.journals.uchicago.edu/doi/pdfplus/10.1086/654439.

Baumeister, C.-Peersman, G. [2012]: The Role of Time-Varying Price Elasticities in Accounting for Volatility Changes in the Crude Oil Market. Journal of Applied Econometrics, Vol. 28. No. 7. 1087-1109. o. http://dx.doi.org/10.1002/jae.2283.

Baumeister, C.-Peersman, G. [2013]: ime-Varying Effects of Oil Supply Shocks on the US Economy. American Economic Journal: Macroeconomics, Vol. 5. No. 4. 1-28. o. http:// dx.doi.org/10.1257/mac.5.4.1.

BERNANKE, B. S. [1983]: Irreversibility, Uncertainty, and Cyclical Investment. Quarterly Journal of Economics, MIT Press. Vol. 98. No. 1. 85-106. o. http://dx.doi.org/10.2307/1885568.

Bernanke, B. S.-Mark Gertler, M.-Watson, M. [1997]: Systematic Monetary Policy and the Effects of Oil Price Shocks. Brookings Papers on Economic Activity, Economic Studies Program, The Brookings Institution, Vol. 28. No. 1. 91-157. o. http://dx.doi. org/10.2307/2534702.

Blanchard, O. J.-Galí, J. [2007]: The Macroeconomic Effects of Oil Price Shocks: Why are the 2000s so different from the 1970s? NBER Chapters. International Dimensions of Monetary Policy, 373-421. o. http://dx.doi.org/10.3386/w13368.

Bodenstein, M.-Guerrieri, L. [2011]: Oil efficiency, demand, and prices: A tale of ups and downs. International Finance Discussion Papers, 1031. Board of Governors of the Federal Reserve System (U. S.).

Bodenstein, M.-Guerrieri, L.-Kilian, L. [2012]: Monetary Policy Responses to Oil Price Fluctuations. IMF Economic Review, Vol. 60. No. 4. 470-504. o. http://dx.doi.org/10.1057/ imfer.2012.19.

Bradley, P. C.-Polson, N. G.-Stoffer, D. S. [1992]: A Monte Carlo Approach to Nonnormal and Nonlinear State-Space Modeling. Journal of the American Statistical Association, Vol. 87. No. 418. 493-500. o. http://dx.doi.org/10.1080/01621459.1992.10475231.

DARVAS ZsolT-VARGA BALÁzs [2014]: Inflation persistence in central and eastern European countries. Applied Economics, Vol. 46. No. 13. 1437-1448. o. http://dx.doi.org/10.1080/00 036846.2013.875113.

Dhawan, R.-Jeske, K. [2008]: Energy Price Shocks and the Macroeconomy: The Role of Consumer Durables. Journal of Money, Credit and Banking, Vol. 40. No. 7. 1357-1377. o. http://dx.doi.org/10.1111/j.1538-4616.2008.00163.x. 
Edelstein, P.-Kilian, L. [2009]: How sensitive are consumer expenditures to retail energy prices? Journal of Monetary Economics, Vol. 56. No. 6. 766-779. o. http://dx.doi. org/10.1016/j.jmoneco.2009.06.001.

Fattouh, B.-Kilian, L.-Mahadeva, L. [2013]: The Role of Speculation in Oil Markets: What Have We Learned So Far? The Energy Journal, Vol. 34. No. 3. http://dx.doi. org/10.5547/01956574.34.3.2.

Fattoun, B.-Mahadeva, L. [2014]: Causes and Implications of Shifts in Financial Participation in Commodity Markets. Journal of Futures Markets, Vol. 34. No. 8. 757-787. o. http:// dx.doi.org/10.1002/fut.21674.

Feyrer, J.-Mansur, E.-SAcerdote, B. [2015]: Geographic Dispersion of Economic Shocks: Evidence from the Fracking Revolution. NBER Working Paper Series, 21624. National Bureau of Economic Research. http://dx.doi.org/10.3386/w21624.

Finn, M. G. [2000]: Perfect Competition and the Effects of Energy Price Increases on Economic Activity. Journal of Money, Credit and Banking, Vol. 32. No. 3. 400-416. o. http:// dx.doi.org/10.2307/2601172.

Goncalves, S.-Kilian, L. [2004]: Bootstrapping autoregressions with conditional heteroskedasticity of unknown form. Journal of Econometrics, Vol. 123. No. 1. 89-120. o. http:// dx.doi.org/10.1016/j.jeconom.2003.10.030.

Green, E. J.-Porter, R. H. [1984]: Noncooperative Collusion under Imperfect Price Information. Econometrica, Econometric Society, Vol. 52. No. 1. 87-100. o. http://dx.doi. org/10.2307/1911462.

Hamilton, J. D. [1994]: Time series analysis. Princeton University Press, Princeton.

Hamilton, J. D. [2003]: What is an oil shock? Journal of Econometrics, Elsevier, Vol. 113. 2. 363-398. o. http://dx.doi.org/10.1016/s0304-4076(02)00207-5.

Hamilton, J. D. [2009]: Causes and Consequences of the Oil Shock of 2007-08. Brookings Papers on Economic Activity, Economic Studies Program, The Brookings Institution, Vol. 40. No. 1. 215-261. o. http://dx.doi.org/10.1353/eca.0.0047.

Hamilton, J. D. [1988]: A Neoclassical Model of Unemployment and the Business Cycle. Journal of Political Economy, University of Chicago Press, Vol. 96. No. 3. 593-617. o. http:// dx.doi.org/10.1086/261553.

IMF [2011]: Oil Scarcity, Growth and Global Imbalances. World Economic Outlook, International Monetary Fund, Washington D.C. 89-124. o.

JIMÉNEZ-RoDRÍGUEZ, R.-SÁNCHEZ, M. [2005]: Oil price shocks and real GDP growth: empirical evidence for some OECD countries. Applied Economics, Vol. 37. No. 2. 201-228. o. http://dx.doi.org/10.1080/0003684042000281561.

Kilian, L. [2009]: Not All Oil Price Shocks Are Alike: Disentangling Demand and Supply Shocks in the Crude Oil Market. American Economic Review, Vol. 99. No. 3. 1053-1069. o. http://dx.doi.org/10.1257/aer.99.3.1053.

Kilian, L. [2010]: Oil Price Shocks, Monetary Policy and Stagflation. Megjelent: Fry, R.Jones, C.-Kent, C. (szerk.): Inflation in an Era of Relative Price Shocks. RBA Annual Conference, Reserve Bank of Australia, 60-84. o. http://www.rba.gov.au/publications/confs/ 2009/pdf/kilian.pdf.

Kilian, L. [2014]: Oil Price Shocks: Causes and Consequences. Annual Review of Resource Economics, Vol. 6. No. 1. 133-154. o. http://dx.doi.org/10.1146/annurev-resource-083013-114701.

KILIAN, L.-LEE, T. K. [2014]: Quantifying the speculative component in the real price of oil: The role of global oil inventories. Journal of International Money and Finance, Vol. 42. 71-87. o. http://dx.doi.org/10.1016/j.jimonfin.2013.08.005. 
Kilian, L.-Murphy, D. P. [2013]: The Role of Inventories and Speculative Trading in the Global Market for Crude Oil. Journal of Applied Econometrics, Vol. 29. No. 3. 454-478. o. http://dx.doi.org/10.1002/jae.2322.

Kilian, L.-PARK, C. [2009]: The Impact Of Oil Price Shocks On The U.S. Stock Market. International Economic Review, Department of Economics, University of Pennsylvania and Osaka University Institute of Social and Economic Research Association, Vol. 50. No. 4. 1267-1287. o. http://dx.doi.org/10.1111/j.1468-2354.2009.00568.x.

KNITTEL, C. R.-PINDYCK, R. S. [2013]: The simple economics of commodity price speculation. NBER Working Paper Series, 18951. http://www.nber.org/papers/w18951.

LI, Z.-Zhно, H. [2011]: Not all demand oil shocks are alike: disentangling demand oil shocks in the crude oil market. Journal of Chinese Economic and Foreign Trade Studies, Vol. 4. No. 1. 28-44. o. http://dx.doi.org/10.1108/17544401111106798.

MacKinnon, J. G. [1996]: Numerical distribution functions for unit root and cointegration tests. Journal of Applied Econometrics, Vol. 11. No. 6. 601-618. o.

Mankiw, G. N. [1999]: Makroökonómia. Osiris Kiadó. Budapest.

Meinhold, R. J.-Singpurwalla, N. D. [1989]: Robustification of Kalman Filter Models. Journal of the American Statistical Association, Vol. 84. No. 406. 479-486. o. http://dx.doi. org/10.2307/2289933.

Montana, G.-Triantafyllopoulos, K.-Tsagaris, T. [2009]: Flexible Least Squares for Temporal Data Mining and Statistical Arbitrage. Expert Systems with Applications, Vol. 36. No. 2. 2819-2830. o. http://dx.doi.org/10.1016/j.eswa.2008.01.062.

Mork, K. A. [1994]: Business Cycles and the Oil Market. The Energy Journal, Vol. 15. No. 1. 15-37. o. http://dx.doi.org/10.5547/issn0195-6574-ej-vol15-nosi-3.

Naveau, P.-Genton, M. G.-Shen, X. [2005]: A skewed Kalman filter. Journal of Multivariate Analysis, Vol. 94. No. 2. 382-400. o. http://dx.doi.org/10.1016/j.jmva.2004.06.002.

Peersman, G.-Stevens, A. [2010]: Oil Demand and Supply Shocks: an Analysis in an Estimated DSGE-Model. (Work In Progress) http://www.suomenpankki.fi/en/tutkimus/ konferenssit/konferenssit_tyopajat/Documents/DSGE2010/DSGE2010_PeersmanStevens_paper.pdf.

Peersman, G.-Van Robays, I. [2012]: Cross-country differences in the effects of oil shocks. Energy Economics, Vol. 34. No. 5. 1532-1547. o. http://dx.doi.org/10.1016/j.eneco. 2011.11.010.

Perotti, R. [2012]: The “Austerity Myth”. Gain Without Pain? NBER Chapters. Megjelent: Fiscal Policy after the Financial Crisis. NBER Working Paper Series, 17571. http://dx.doi. org/10.3386/w17571.

Rotemberg, J. J.-Woodford, M. [1996]: Imperfect Competition and the Effects of Energy Price Increases on Economic Activity. Journal of Money, Credit and Banking, Vol. 28. No. 4. 549-577. o. http://dx.doi.org/10.2307/2078071.

SMith, R. L.-Miller J. E. [1986]: A non-Gaussian state space model and application to prediction of records. Journal of the American Statistical Association. Series B, Vol. 48. No. 1. 79-88. o.

VARGA BALÁzs [2011]: Időben változó változó együtthatójú ökonometriai modellek. Statisztikai Szemle, 89. évf. 7-8. sz. 813-838. o.

VARGA BALÁzs [2014]: Méri-e a tőkepiacok nyitottságát a beruházás és a megtakarítás időben változó kapcsolata? Statisztikai Szemle, 92. évf. 3. sz. 225-252. o. 


\section{Függelék}

A következő oldalakon lévő F1-F3. ábra a Kalman-szürős modellből nyert eredményeket tartalmazza. Minden esetben az ábracímben megjelölt, egységnyi nagyságú sokkhoz tartozó kumulált impulzusválasz-függvényeket ábrázoltuk, azaz a makrogazdasági változó szintjében bekövetkezett változást, az alappályától (a sokk nélküli esettől) való százalékos (munkanélküliségi ráta esetében százalékpontos) eltérést. A kínálati sokknál egy nem várt termeléskiesés hatása szerepel. Mindhárom ábra azonos struktúrát követ. Az első oszlopban az egységnyi sokk adott makrováltozó (CPI, GDP-deflátor, GDP, munkanélküliségi ráta) szintjére gyakorolt hatása szerepel három évre előre, negyedéves bontásban, öt különböző időpontban, azaz attól függöen, hogy a nem várt változás mikor következett be. A vizsgált negyedévek a következők: 1978. I. negyedév, 1987. IV. negyedév, 1996. IV. negyedév, 2005. IV. negyedév, 2014. IV. negyedév. A második oszlopban szintén a kumulált impulzusválasz-függvények szerepelnek: itt azt mutatják meg, hogy egységnyi sokknak milyen hatása volt az adott változó szintjére 0, 1, 2 és 3 évvel a bekövetkezése után, attól függően, hogy ez a sokk melyik negyedévben (vízszintes tengely) következett be. Az ábrák harmadik oszlopában található hőtérképek e szignifikanciapróbák eredményeit ábrázolják. A vízszintes tengelyen a sokk bekövetkezésének időpontja szerepel, míg a függőleges tengely rögzített, mindig 0-12 negyedévet jelöl. A hötérkép gyakorlatilag egy mátrix, aminek $(i ; j)$ eleme azt mutatja, hogy a $j$-edik negyedévben bekövetkező sokk hatása szignifikáns-e $i$ negyedévvel a bekövetkezés után (az ábrán a legfelső sorban a 12 negyedévvel későbbi hatás szerepel, míg az azonnali hatáshoz az alsó sor tartozik). Ha a hatás a két standard hibányi konfidencia-intervallum mellett is szignifikáns, akkor a mező fekete, ha csak egy standard hiba mellett tekinthető statisztikailag nullától különbözőnek, akkor szürke, minden egyéb esetben, tehát amikor a hatás nem szignifikáns, fehér. 


\section{F1. ábra}

Egységnyi kínálati sokk hatása az Egyesült Államok makrogazdasági mutatóira (időben változó paraméterű modell eredményei)

\section{Egységnyi sokk hatása}

\begin{tabular}{ccc}
\hline $\begin{array}{c}\text { három évre elöre a sokk } \\
\text { bekövetkezésétől }\end{array}$ & $\begin{array}{c}0-3 \text { évvel a sokk } \\
\text { bekövetkezése után }\end{array}$ & Szignifikancia-hőtérkép \\
\hline
\end{tabular}
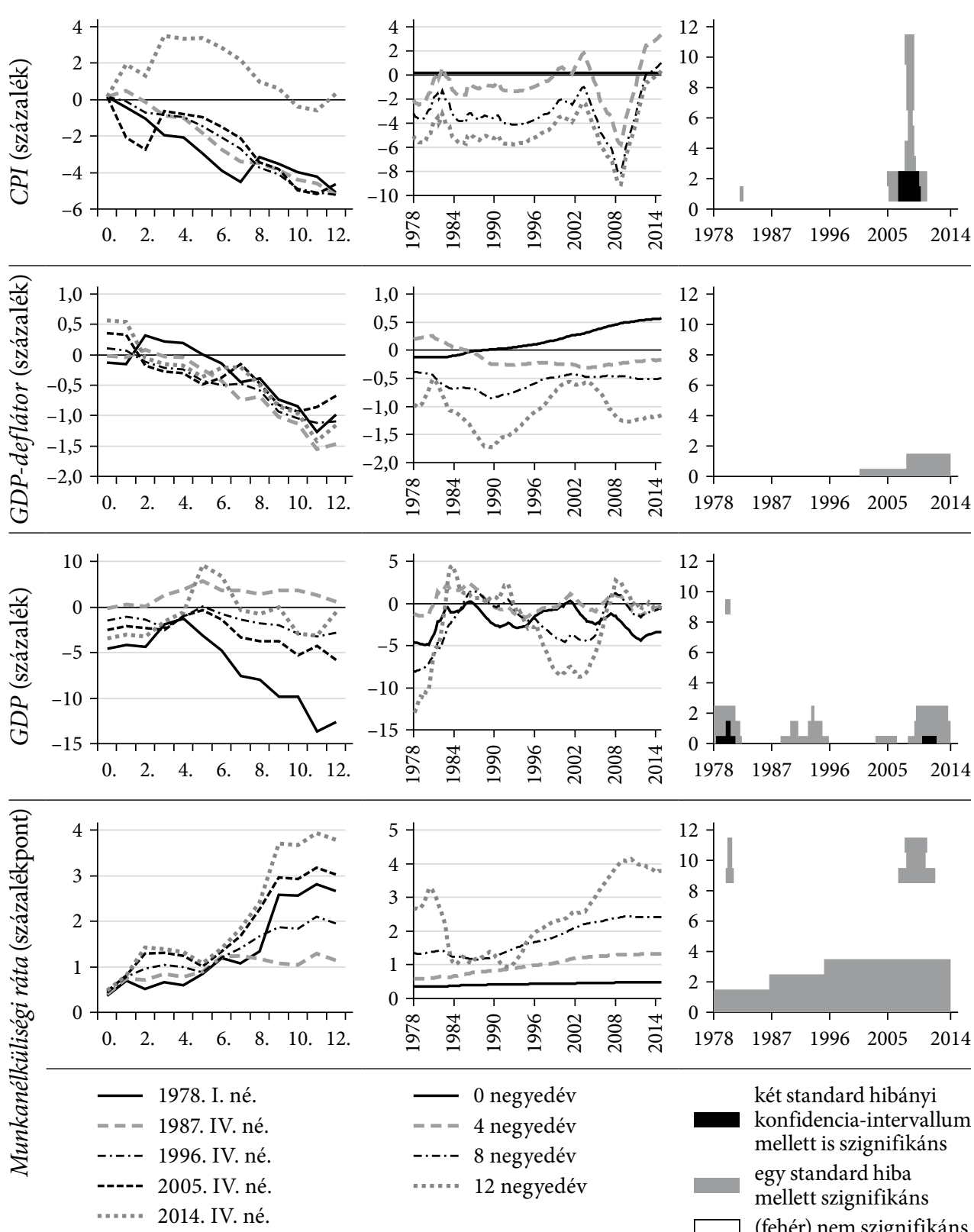

két standard hibányi konfidencia-intervallum mellett is szignifikáns egy standard hiba mellett szignifikáns (fehér) nem szignifikáns

Forrás: saját szerkesztés. 


\section{F2. ábra}

Egységnyi aggregált keresleti sokk hatása az Egyesült Államok makrogazdasági mutatóira (időben változó paraméterű modell eredményei)

Egységnyi sokk hatása
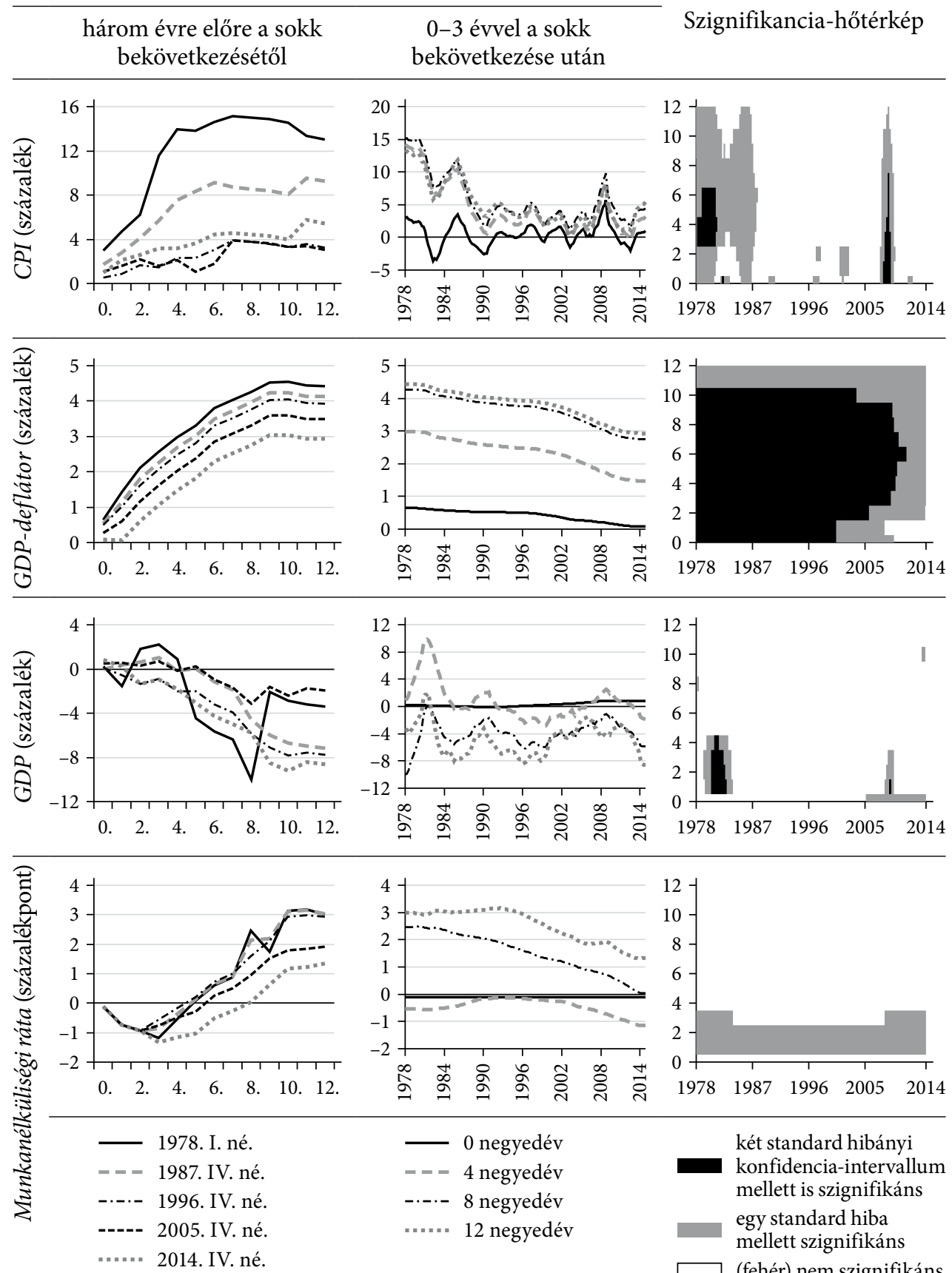

két standard hibányi konfidencia-intervallum mellett is szignifikáns egy standard hiba mellett szignifikáns (fehér) nem szignifikáns

Forrás: saját szerkesztés. 


\section{F3. ábra}

Egységnyi specifikus keresleti sokk hatása az Egyesült Államok makrogazdasági mutatóira (időben változó paraméterű modell eredményei)

\section{Egységnyi sokk hatása}

\begin{tabular}{ccc}
\hline $\begin{array}{c}\text { három évre előre a sokk } \\
\text { bekövetkezésétől }\end{array}$ & $\begin{array}{c}0-3 \text { évvel a sokk } \\
\text { bekövetkezése után }\end{array}$ & Szignifikancia-hötérkép \\
\hline
\end{tabular}

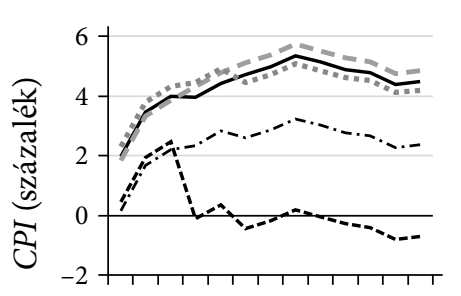

0. 2. $4.6 . \quad 8.10 .12$. 12.
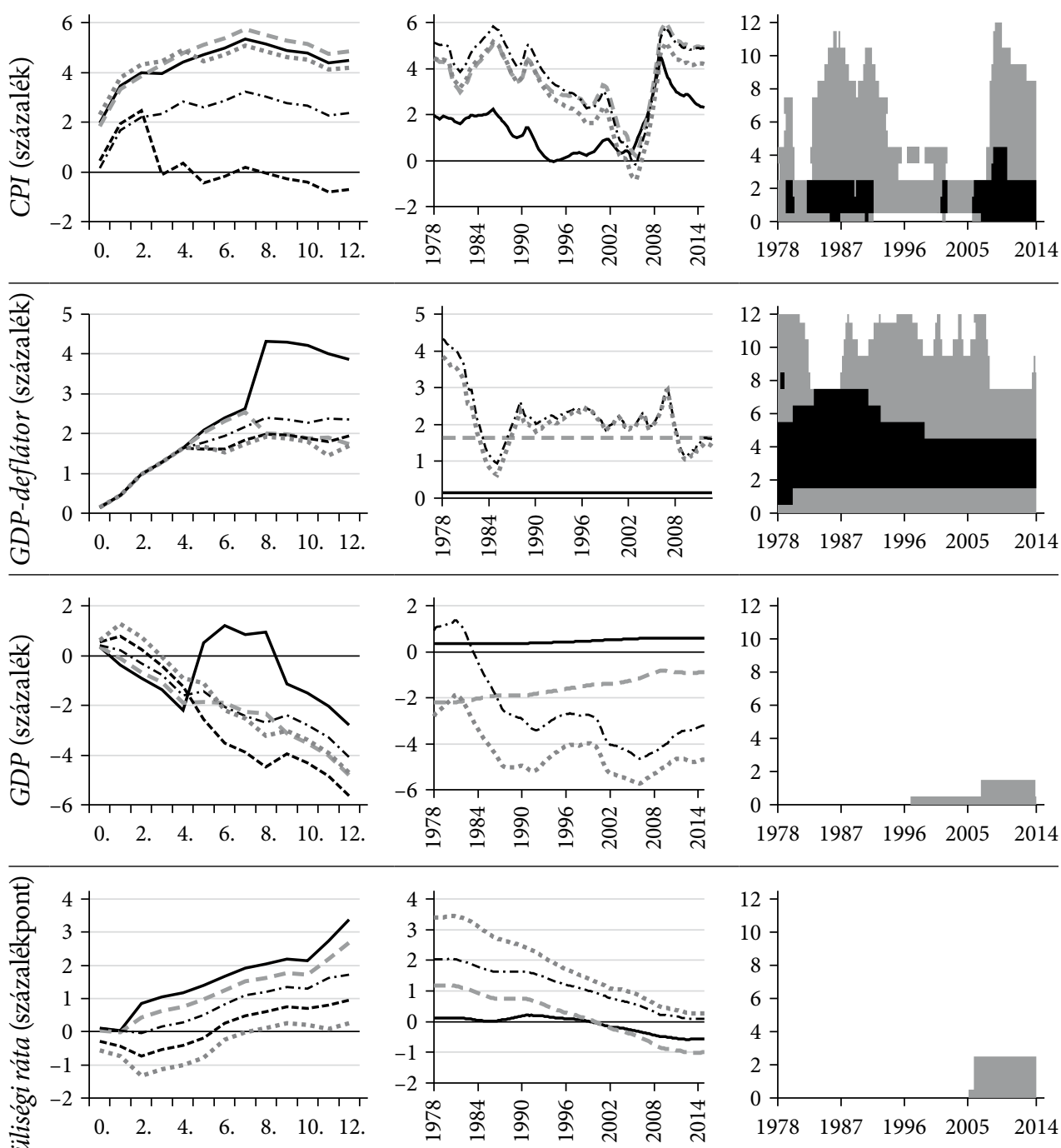

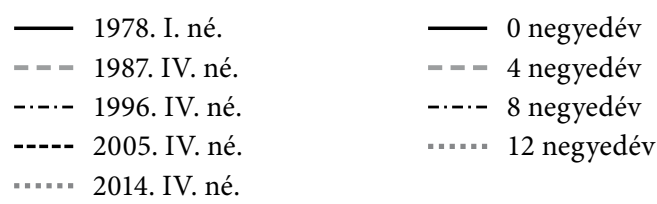

két standard hibányi konfidencia-intervallum mellett is szignifikáns egy standard hiba mellett szignifikáns (fehér) nem szignifikáns

Forrás: saját szerkesztés. 